WSRC-TR-2001-00084

Revision 0

\title{
High Purity Germanium $\gamma$-PHA Assay of Uranium Scrap Cans Used in 321-M Facility
}

\section{Saleem R. Salaymeh, Raymond A. Dewberry, and Vito Casella}


WSRC-TR-2001-00084

Revision 0

Keywords: Deming, Multichannel, Far field, Assay, Spectrum, Holdup

Classification: $\mathrm{U}$ P.E. Filpus-Lupckx Authorized Derivative Classifier

H igh Purity Germanium $\boldsymbol{\gamma}$-PHA Assay of Uranium Scrap Cans Used in 321-M Facility

Saleem R. Salaymeh Raymond A. Dewberry, and Vito Casella Publication Date: December 18, 2001

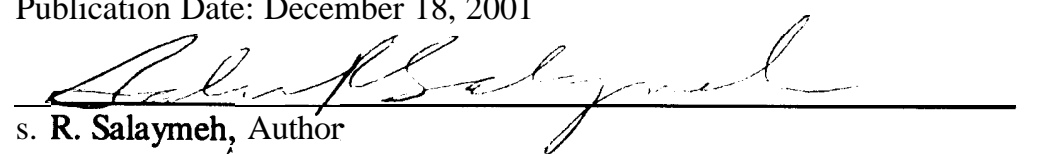

$\frac{0 / 14 / 02}{\text { Date }}$
$\frac{14 K_{i i} C_{2}}{\text { Date }}$
$\frac{01 / 14 / 02}{\text { Date }}$
$\frac{1 / 5 / 02}{\text { Date }}$
$\frac{01 / 16 / 02}{\text { Date }}$
$\frac{01 / 17 / 02}{\text { Date }}$

Westinghouse Savannah River Company Savannah River Site $\quad 4$ Aiken, SC 29808

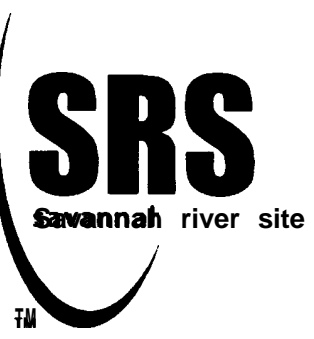


This document was prepared in conjunction with work accomplished under Contract No.

DE-AC09-96SR18500 with the U.S. Department of Energy.

\begin{abstract}
DISCLAIMER
This report was prepared as an account of work sponsored by an agency of the United States Government. Neither the United States Government nor any agency thereof, nor any of their employees, makes any warranty, express or implied, or assumes any legal liability or responsibility for the accuracy, completeness, or usefulness of any information, apparatus, product or process disclosed, or represents that its use would not infringe privately owned rights. Reference herein to any specific commercial product, process or service by trade name, trademark, manufacturer, or otherwise does not necessarily constitute or imply its endorsement, recommendation, or favoring by the United States Government or any agency thereof. The views and opinions of authors expressed herein do not necessarily state or reflect those of the United States Government or any agency thereof.
\end{abstract}

This report has been reproduced directly from the best available copy.

Available for sale to the public, in paper, from:

U.S. Department of Commerce

National Technical Information Service

5285 Port Royal Road

Springfield, VA 22161

phone: (800) 553-6847

fax: (703) 605-6900

email: orders@ntis.fedworld.gov

online ordering: http://www.ntis.gov/support/index.html

Available electronically at http://www.doe.gov/bridge

Available for a processing fee to U.S. Department of Energy and its contractors, in paper, from:

U.S. Department of Energy

Office of Scientific and Technical Information

P.O. Box 62

Oak Ridge, TN 37831-0062

phone: (865)576-8401

fax: (865)576-5728

email: reports@adonis.osti.gov 


\section{ABSTRACT}

The Analytical Development Section of SRTC was requested by the Facilities

Disposition Division (FDD) to determine the holdup of enriched uranium in the 321-M facility as part of an overall deactivation project of the facility. The 321-M facility was used to fabricate enriched uranium fuel assemblies, lithium-aluminum target tubes, neptunium assemblies, and miscellaneous components for the production reactors. The facility also includes the 324-M storage building and the passageway connecting it to 321-M. The results of the holdup assays are essential for determining compliance with the Solid Waste's Waste Acceptance Criteria, Material Control \& Accountability, and to meet criticality safety controls. This report describes and documents the use of a portable HPGe detector and EG\&G DART ${ }^{\circledR}$ system that contains a high voltage power supply, signal processing electronics, a personal computer with Gamma-Vision software, and space to store and manipulate multiple 4096-channel $\gamma$-ray spectra to assay for ${ }^{235} \mathrm{U}$ content. The system was used to assay a large number of scrap cans used to store highly enriched uranium (HEU) chips and filings. This report includes a description of two efficiency calibration configurations and also the results of the assay. A description of the quality control checks is included as well. 
WSRC-TR-2001-00084

Revision 0

December 18, 2001

Page 5 of 32

This page intentionally left blank. 


\section{TABLE OF CONTENTS}

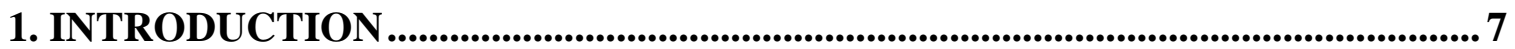

2. EXPERIMENTAL _................................................................................................... 8

2.1 TRANSMISSION CORRECTION TECHNIQUE............................................................................... 13

2.2 DEMING INTERACTIVE QUADRATIC CURVE MEASUREMENT .......................................... 14

3. DISCUSSION ................................................................................................................................25

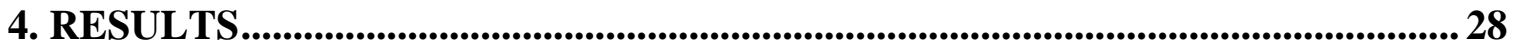

5. CONCLUSION........................................................................................................................31

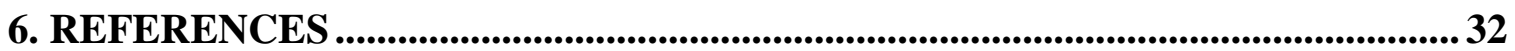

\section{LIST OF FIGURES}

Figure 1. A photograph of the assay station in Building 324-M ...................................... 8

Figure 2. A closer view of the components used for the data acquisition .....................9

Figure 3. 324-M Background Spectrum.................................................................................. 11

Figure 4. Standard 2021A Spectrum Acquired at the 324-M Assay Station ..............11

Figure 5. A photo showing the scrap can that was used for calibration ......................13

Figure 6. Deming Calibration Curve Used to Obtain ${ }^{235} \mathrm{U}$ Gram Value...................... 15

Figure 7. Photograph of a cyclone separator can .................................................................. 28

\section{LIST OF TABLES}

Table 1. List of data used to obtain empty scrap can transmission correction 12

Table 2. Measured sample and transmission data for the 321-M scrap cans assayed

for HEU content in this report ...................................................................................... 16

Table 3. Initial Deming Data ..................................................................................................... 15

Table 4. Reported Values for Assay of HEU Standards by Both Techniques............ 25

Table 5. A list the reported values of scrap cans grouped by component.................... 29 
WSRC-TR-2001-00084

Revision 0

December 18, 2001

Page 7 of 32

\title{
High Purity Germanium $\gamma$-PHA Assay of Uranium Scrap Cans Used in 321-M Facility
}

\author{
Saleem R. Salaymeh, Raymond A. Dewberry, and Vito Casella \\ Westinghouse Savannah River Company \\ Savannah River Site \\ Aiken SC 29808
}

\section{INTRODUCTION}

The 321-M facility was used to fabricate highly enriched uranium (HEU) fuel assemblies, lithium-aluminum target tubes, neptunium assemblies, and miscellaneous components for the production reactors. The facility also includes the 324-M storage building and the passageway connecting it to $321-\mathrm{M}$. The facility operated for 25 years. During this time thousands of uranium-aluminum-alloy (U-Al) fuel tubes were produced. After the facility ceased operations in 1995, all of the easily accessible U-Al was removed from the building, and only residual amounts remained. The bulk of this residue is located in the equipment that generated and handled small U-Al particles and in the exhaust systems for this equipment (e.g., chip compactor, casting furnaces, $\log$ saw, lathes A \& B, cyclone separator, Freon ${ }^{\mathrm{TM}}$ cart, riser crusher, ... etc). ${ }^{1}$ In addition to these examples there are 268 pigs that were used for storage and shipping of HEU.

Facilities Disposition Division (FDD) has requested technical assistance from the Analytical Development Section (ADS) of the Savannah River Technology Center to determine the holdup of enriched uranium in the 321-M facility as part of an overall deactivation project of the facility. ${ }^{2}$ This project includes the dismantling and removal of all HEU to the extent practical. ADS was tasked to conduct holdup assays and waste residue assays of all components removed from the facility. A large number of scrap cans was used by the facility to store highly enriched uranium chips and filings for reprocessing. The scrap cans were designed to be critically safe, which made them extremely useful during the deactivation of the facility. These cans provided a geometrically safe container for placement of the residue, filings, chips, and sweepings of HEU remaining in the building. Since the assays are important for material control and accountability (MC\&A), criticality safety, and waste management purposes, it was important to obtain the best gram value possible. The method of choice for determining the HEU content in each scrap can is by using nondestructive assay (NDA).

To accomplish this, we set up an assay station in 324-M that consisted of a turntable and portable HPGe gamma pulse height analysis system ( $\gamma$-PHA). The 324-M assay station was especially suited to obtain a transmission-corrected assay of each of these fixed geometry scrap cans. This report discusses the detector efficiency calibration and use of the portable HPGe detection system ${ }^{3}$ to obtain an assay of ${ }^{235} \mathrm{U}$ content in each scrap can. 


\section{EXPERIMENTAL}

A photograph of the assay station that we assembled in Building 324-M is shown in Figure 1. Figure 2 shows a closer view of the components used for the data acquisition. In Figure 2 it is clear that the assay station was assembled so that the portable HPGe detector views the sample scrap can in a far field configuration. At the 324-M station the scrap can stands on a turntable of fixed height inside of a contamination area (CA). The portable detector was adjusted to the optimum height so that it views the scrap can with greatest efficiency from outside of the CA. The sample to detector distance is fixed at 48 inches. Behind the scrap can turntable shown in both Figures 1 and 2 is the transmission source stand. The stand is set so that the removable source of $4.41 \mathrm{~g} \mathrm{U}-235$ will be at a fixed source to detector distance of 63 inches and so that photons from decay of it must pass through the sample scrap can to interact with the detector.

The photograph in Figure 1 shows three personal computers (PC) used at the assay station. The acquisition and analysis system consists of the portable HPGe detector, an EG\&G DART ${ }^{\circledR}$ electronics package shown on the extreme left of the assay table, and the PC immediately to the right of the DART ${ }^{\circledR}$ electronics box. The DART ${ }^{\circledR}$ system contains the high voltage power supply and the signal processing electronics. The PC contains the Gamma-Vision software that converts it to a full function multi-channel analyzer for data acquisition and analysis. ${ }^{3}$

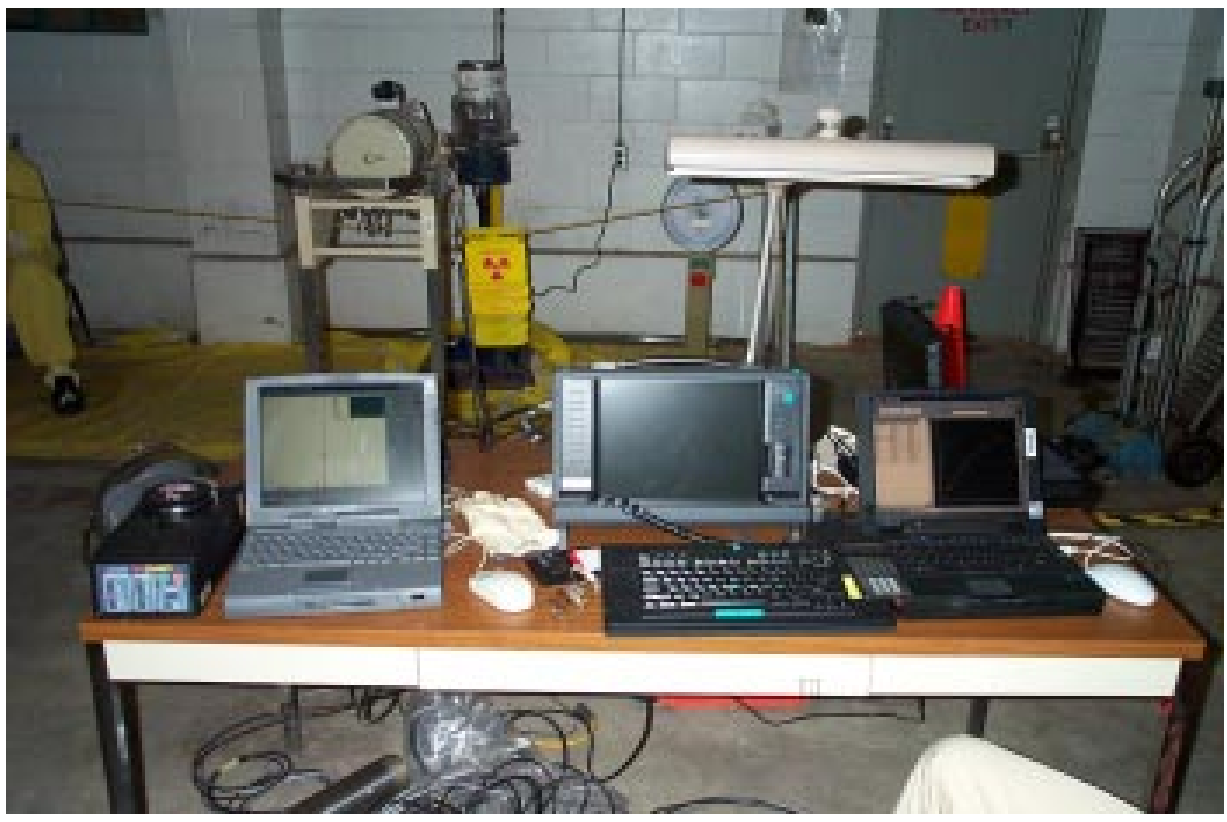

Figure 1. A photograph of the assay station in Building 324-M.

The PC in the center of the assay table in Figure 1 contains a Microsoft ${ }^{\circledR}$ excel spreadsheet that we wrote to allow us to provide on the spot results for the transmission corrected far field assays. The spreadsheet is constructed so the input data of counting 
time and peak area in the $185.70 \mathrm{KeV}$ region of interest in the sample $\gamma$-ray spectrum and sample transmission spectrum instantly yield the transmission correction value as well as assay results and uncertainty for each can. The third PC on the right of the table in Figure 1 contains a Deming least squares quadratic curve that provides us with a second assay result based on a stored transmission correction curve. ${ }^{4}$ We provide further details of the Microsoft ${ }^{\circledR}$ excel spreadsheet and of the Deming curve in the next section. All of the acquisition, analysis, spreadsheet calculations, and curve fitting software could have been run on a single PC, but having three available eliminated the requirement of continually moving the software around the desktop.

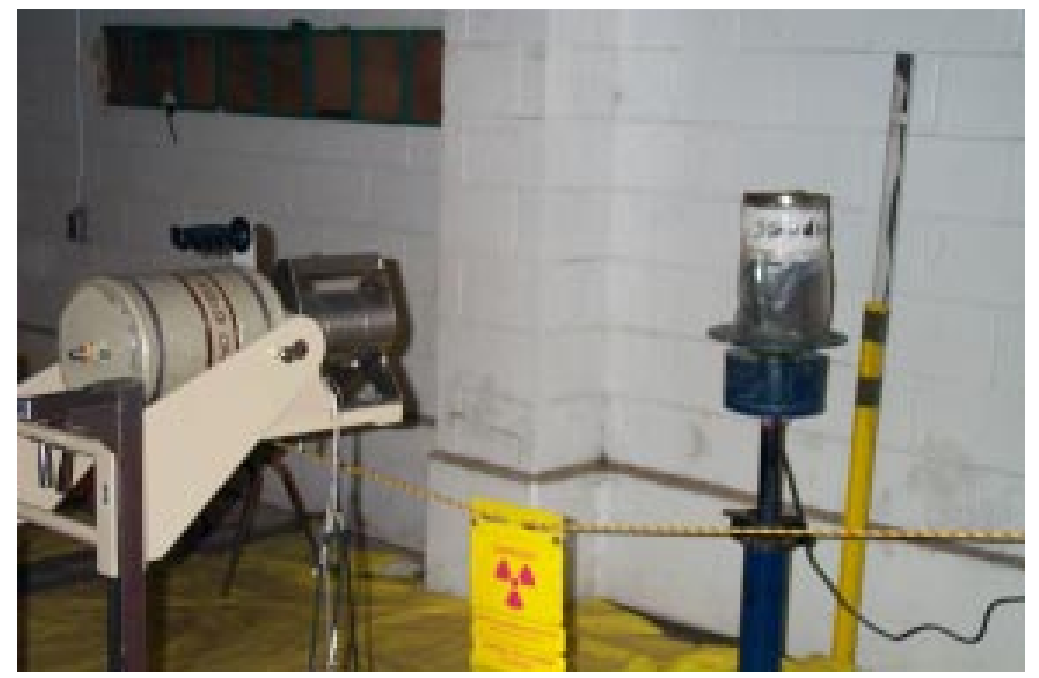

Figure 2. A closer view of the components used for the data acquisition.

A sample assay consists of performing two $\gamma$-PHA acquisitions with each can. One acquisition is performed on the scrap can alone and a second is performed with the transmission source placed behind the scrap can on the fixed stand. The second acquisition then contains sample events and transmission source events in the $185 \mathrm{KeV}$ $\gamma$-ray region of interest. The transmission attribute of each sample can is calculated from

$$
\mathrm{T}(\operatorname{can})=\frac{\operatorname{cps}(\operatorname{can} \mathrm{T})-\operatorname{cps}(\operatorname{can})}{\operatorname{cps}(\text { source })},
$$

where $\operatorname{cps}(\operatorname{canT})$ is the sample plus transmission source rate, $\operatorname{cps}(\mathrm{can})$ is the can-only rate, and cps(source) is the source-only rate. The source-only rate is obtained with each shift of acquisitions, and serves also as a quality control (QC) check for each shift of analyses.

For the QC check, the 4.41-g source is counted at a distance of 63 inches and is analyzed by equation (2). 


$$
{ }^{235} \mathrm{U}=\left(\mathrm{K}_{\mathrm{p}}\right)(\mathrm{cps})(\mathrm{d})^{2}=\left(2.36 \times 10^{-5}\right)(\mathrm{cps})(63 \times 2.54)^{2},
$$

where the first term is the point source calibration constant in units of $\mathrm{g}$-sec/ $/ \mathrm{cm}^{2}$, and dis the acquisition distance in units of $\mathrm{cm}$. Note in Table 2 the T0 acquisition of 7/6/00 had a detection rate of $2210 / 300=7.367$, which yields a measured result of $4.45 \mathrm{~g}$ for the source. This is in extremely good agreement with the known content of $4.41 \mathrm{~g}$. In subsequent $\mathrm{QC}$ checks we required the $\mathrm{T} 0 \mathrm{QC}$ check to have a detection rate of $7.30 \pm 0.73 \mathrm{cps}$.

The measured contents of each can are calculated using the transmission-corrected point source configuration of equation (3).

$$
{ }^{235} \mathrm{U}=\left(\mathrm{K}_{\mathrm{p}}\right)(\mathrm{cps})(\mathrm{d})^{2}(\mathrm{Cf})=\left(2.36 \times 10^{-5}\right)(\mathrm{cps})(48 \times 2.54)^{2}(\mathrm{Cf}),
$$

where the acquisition distance is 48 inches, and $\mathrm{Cf}$ is the transmission correction factor for each can determined from the results of equation (1). For each can $\mathrm{Cf}$ is taken to be $\sqrt{\mathrm{T}}$, where $\mathrm{T}$ is determined from the measured data using (1).

For each can of material, the transmission attribute is a combination of absorption of the $185 \mathrm{KeV} \gamma$-ray by the container and by the ${ }^{235} \mathrm{U}$ residue inside. Therefore every measured correction factor must be at least as large as that of the container (can) alone. In order to determine the can-only transmission, we acquired the data listed in Table 1. These data represent can-only data using several M-Area sources of solid HEU.

Table 1 lists seventeen HPGe spectra acquired at the 324-M scrap can assay station in late April 2000. The first two rows and the fifth row represent background acquisitions, all of which have detection rates of the $185 \mathrm{KeV} \gamma$-ray in agreement with $(0.115 \pm 0.014)$ cps. Figure 3 shows a background spectrum. For the rest of the treatment of the data of Table 1 we do not make the insignificant correction of subtraction of this very small background component.

The third and fourth acquisitions (WT2021At and WT2021Ac) represent traditional measures of the transmission of the $185 \mathrm{KeV} \gamma$-ray through a can that we have designated the standard scrap can. That is, WT2021 At is a QC type spectrum acquired with source 2021a on the transmission source holder exactly as in the spectrum used in equation (2). The $\gamma$-ray spectrum for source 2021a is shown in Figure 4. The standard scrap can is shown in the photograph of Figure 5. Spectrum WT2021Ac was acquired with the standard scrap can placed between the source and the detector to measure the transmission through the standard scrap can. In the last column of Table 1 we have listed the transmission factor for the can alone, which is simply the ratio of the detection rate of acquisition WT2021At to that rate in WT2021Ac. That ratio is $(7.623 \pm 0.122) /(3.563 \pm 0.087)=(2.14 \pm 0.28)$. $($ Henceforth for these Table 1 measurements we do not carry the uncertainty.) In the configuration of these two 
acquisitions the transmission factor of 2.14 represents transmission of the $185 \mathrm{KeV}$ photon through two sides of the standard can. For subsequent acquisitions of Table 1, the configuration represents transmission through only one side of the can, which is representative of how actual samples will be analyzed. Therefore the transmission correction factor is taken to be the $\sqrt{T}=1.46$ for the configuration of the third and fourth acquisitions of Table 1.

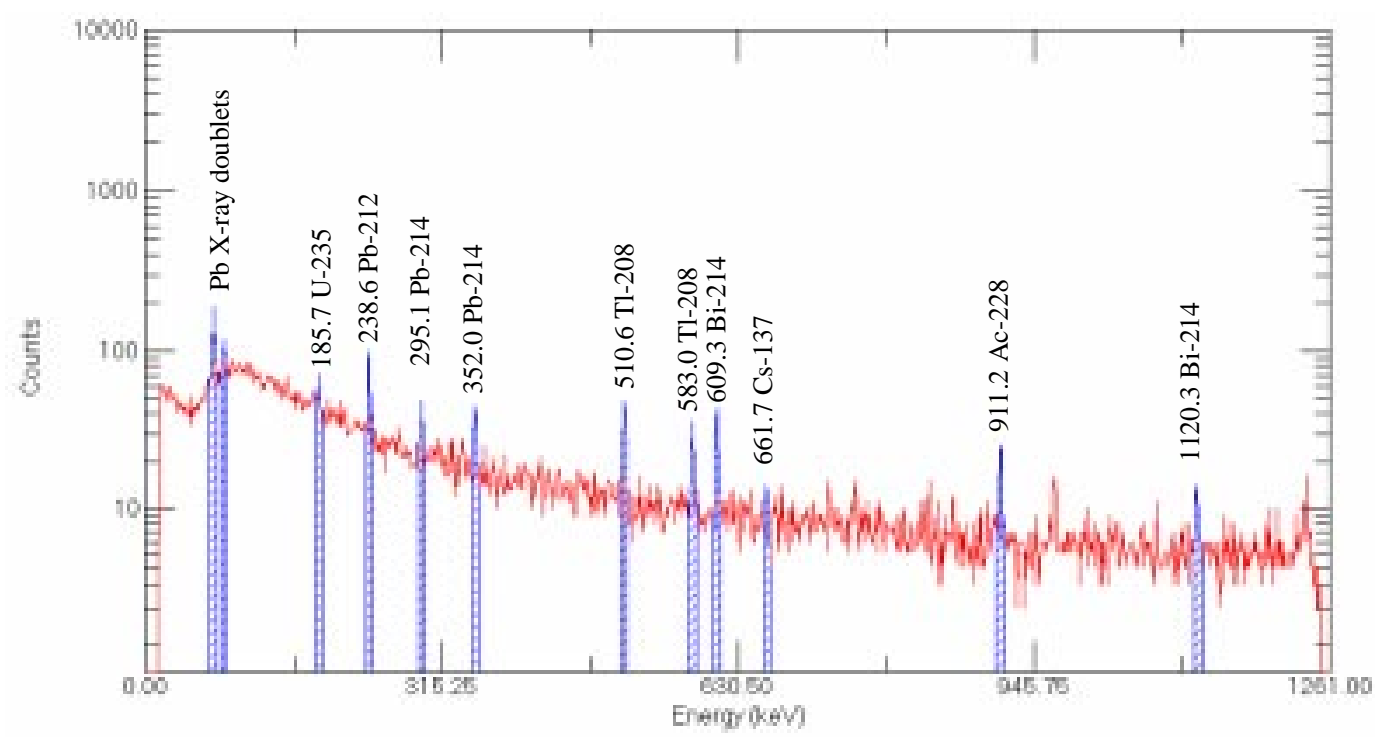

Figure 3. 324-M Background Spectrum.

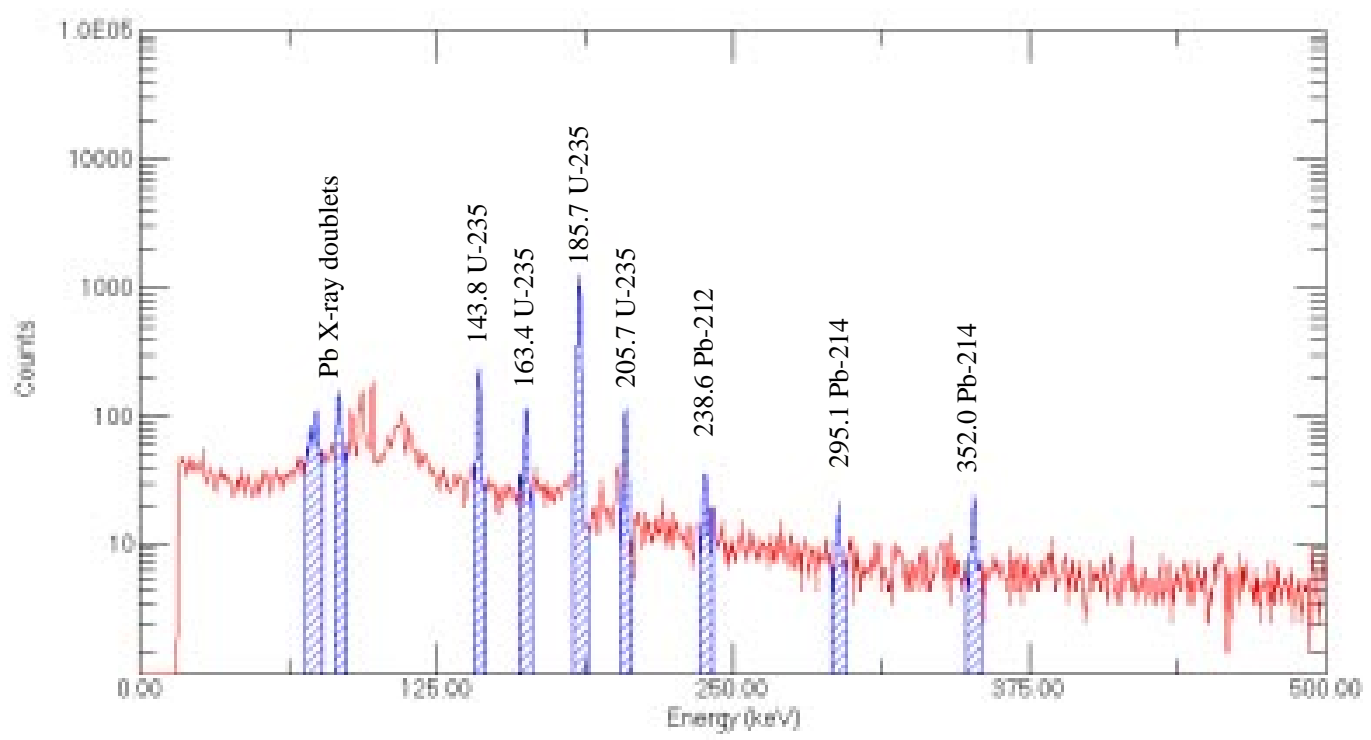

Figure 4. Standard 2021A Spectrum Acquired at the 324-M Assay Station. 
The remaining twelve acquisitions of Table 1 all represent comparisons between spectra acquired from a standard source of ${ }^{235} \mathrm{U}$ inside the standard can with a spectrum acquired from the identical source and distance not inside the can. Thus the ratio of the detection rate of the $185 \mathrm{KeV}$ photon from outside the can to that from inside the can represents an exact measure of the absorption of the photon by the can alone. Using six different sources of ${ }^{235} \mathrm{U}$ content ranging from $0.69 \mathrm{~g}$ to $98.31 \mathrm{~g}$ we obtained the transmission factors listed in the last column of Table 1. These transmission factors represent the transmission correction factor for one can thickness and range from 1.58 to 1.93 . Overall we have seven measures of the can-only transmission correction factor that yield an average and standard deviation of $1.66 \pm 0.15$. Any sample transmission correction factors measured below that range must be considered unrealistically low, and any significantly above that range must be regarded as a sample that contains particularly densely packed residue.

Table 1. List of data used to obtain empty scrap can transmission correction.

\begin{tabular}{|c|c|c|c|c|c|}
\hline $\begin{array}{c}\text { Spectrum } \\
\text { Number }\end{array}$ & Description of Setup & $\begin{array}{c}185 \mathrm{KeV} \\
\text { Area }\end{array}$ & $\begin{array}{c}\text { Count } \\
\text { Time }(s)\end{array}$ & CPS & $\begin{array}{c}\mathbf{T} \\
\text { Corr. }\end{array}$ \\
\hline BKG424-1 & Bkg TT \& T-source holder & $331 \pm 51$ & 2537 & 0.130 & \\
\hline BKG424-2 & Bkg TT \& T-source holder not in view of detec. & $182 \pm 40$ & 1800 & 0.101 & \\
\hline WT2021At & $4.20 \mathrm{~g}$ on T-source holder \& TT w/o sample & $4574 \pm 73$ & 600 & 7.623 & 2.14 \\
\hline WT2021Ac & $\begin{array}{l}4.20 \mathrm{~g} \text { on T-source holder \& TT with std can } \\
(5301) \text { in front of source }\end{array}$ & $2138 \pm 52$ & 600 & 3.563 & \\
\hline std can & std can by itself rotating & $57 \pm 27$ & 600 & 0.095 & \\
\hline WT2023Aic & $.69 \mathrm{~g}$ inside the std can & $932 \pm 31$ & 600 & 1.553 & $1.62 \pm 0.07$ \\
\hline WT2023Aoc & $\begin{array}{l}.69 \mathrm{~g} \text { centered outside the std can \& TT (not } \\
\text { rotating) }\end{array}$ & $1506 \pm 40$ & 600 & 2.51 & \\
\hline WT2021Aic & $4.20 \mathrm{~g}$ inside the std can & $5538 \pm 78$ & 600 & 9.23 & $1.58 \pm 0.03$ \\
\hline WT2021Aoc & $\begin{array}{l}4.20 \mathrm{~g} \text { centered outside the std can \& TT (not } \\
\text { rotating) }\end{array}$ & $8757 \pm 95$ & 600 & 14.59 & \\
\hline WT2014Aic & $1.01 \mathrm{~g}$ inside the std can & $1319 \pm 37$ & 600 & 2.198 & $1.61 \pm 0.06$ \\
\hline WT2014Aoc & $\begin{array}{l}1.01 \mathrm{~g} \text { centered outside the std can \& TT (not } \\
\text { rotating) }\end{array}$ & $2128 \pm 48$ & 600 & 3.546 & \\
\hline WT2016Aic & $39.11 \mathrm{~g}$ inside the std can & $34370 \pm 200$ & 600 & 57.283 & $1.65 \pm 0.01$ \\
\hline WT2016Aoc & $\begin{array}{l}39.11 \mathrm{~g} \text { centered outside the std can \& TT (not } \\
\text { rotating) }\end{array}$ & $56740 \pm 250$ & 600 & 94.566 & \\
\hline WT2019Aic & $15.67 \mathrm{~g}$ inside the std can & $17359 \pm 141$ & 600 & 28.931 & $1.74 \pm 0.02$ \\
\hline WT2019Aoc & $\begin{array}{l}15.67 \mathrm{~g} \text { centered outside the std can \& TT (not } \\
\text { rotating) }\end{array}$ & $30151 \pm 180$ & 600 & 50.251 & \\
\hline WT2026Aic & $98.31 \mathrm{~g}$ inside the std can & $31708 \pm 193$ & 300 & 105.693 & $1.93 \pm 0.01$ \\
\hline WT2026Aoc & $\begin{array}{l}98.31 \mathrm{~g} \text { centered outside the std can \& TT (not } \\
\text { rotating) }\end{array}$ & $61132 \pm 259$ & 300 & 203.773 & \\
\hline \multicolumn{5}{|c|}{ Average Can Transmission Correction } & 1.66 \\
\hline
\end{tabular}




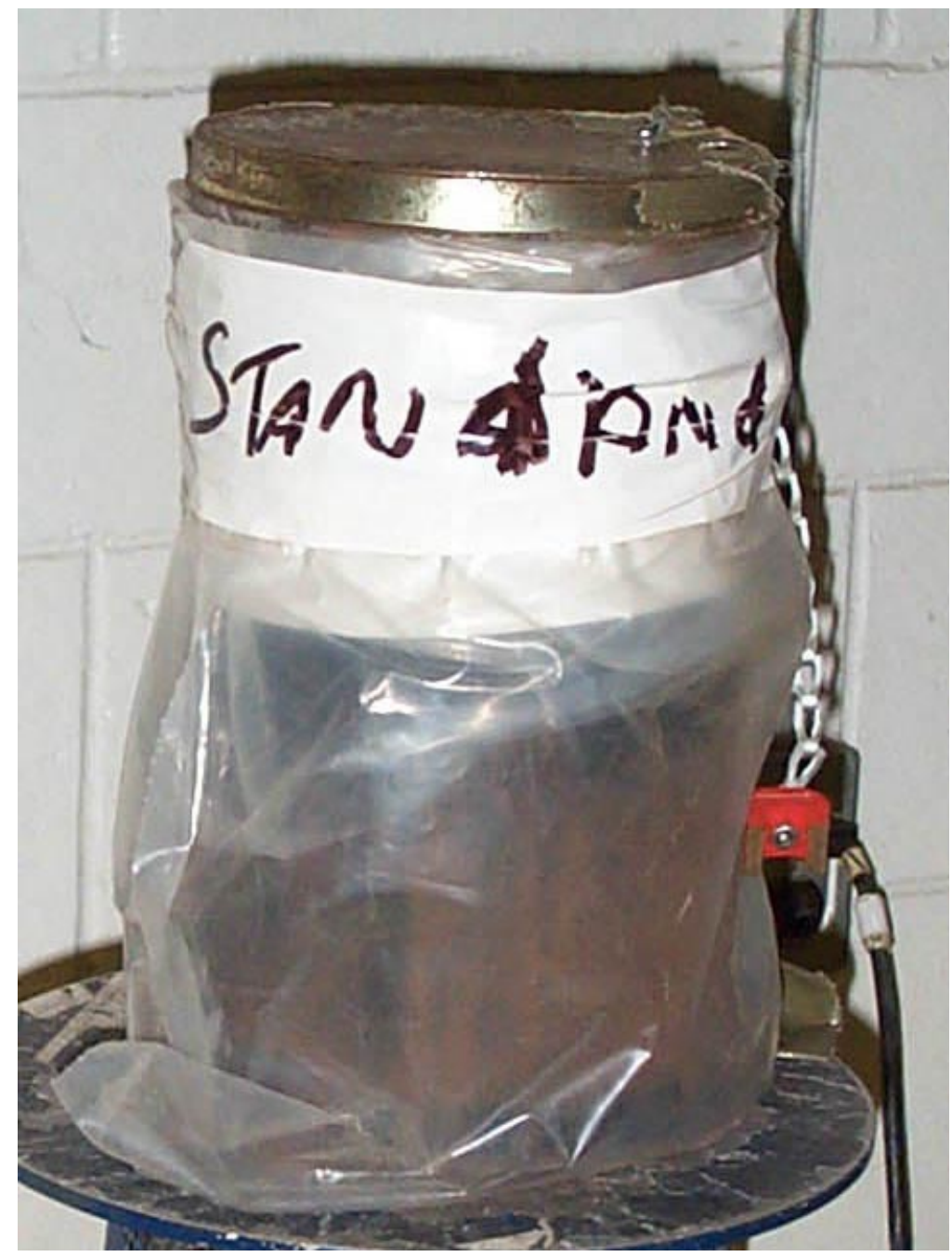

Figure 5. A photo showing the scrap can that was used for calibration.

\subsection{Transmission Correction Technique}

In this report we use two methods of transmission correction for each sample analyzed. Our first method is what would generally be regarded as the traditional shine-through method widely used in $\gamma$-PHA nondestructive assay. ${ }^{5}$ The second method involves an empirical correction using an interactive Deming least squares quadratic curve to assign an assay value. We describe that method in the next section.

The content of each scrap can is measured by the traditional transmission-corrected assay using a combination of data as described above and using equations (1) and (3). Each assay is shown completely in a single line of the spreadsheet of Table 2 . The first two columns in Table 2 designate the acquisition date and the scrap can number. The third column denotes the count time for the sample plus source acquisition, and column four 
lists the area under the $185 \mathrm{KeV}$ peak for this count. Column five denotes the count time for the sample only (no transmission source), and column six denotes the area under the $185 \mathrm{KeV}$ peak for that count. Column seven lists the transmission correction factor for the sample. This value is determined by $\sqrt{\mathrm{T}}$, where $\mathrm{T}$ is calculated from equation (1). The mass of HEU in the can is then calculated by equation (3), and the uncertainty is determined from a propagation of the $2 \sigma$ uncertainties in each of the multi-channel analyzer fits to the areas under the $185-\mathrm{KeV}$ peaks. This uncertainty is propagated in equation (3) in both the (cps) term and in the $\left(\mathrm{Cf}_{\mathrm{t}}\right)$ term.

The two sigma uncertainty for each far-field measurement is given by Equation (4):

$$
2 \sigma_{\mathrm{u}}=\mathrm{M}_{\mathrm{u}} 2 \times \sqrt{\left(\frac{\sigma_{\mathrm{c}}}{\mathrm{C}_{\mathrm{c}}}\right)^{2}+\left(\frac{\sigma_{\mathrm{T}}}{\mathrm{C}_{\mathrm{T}}}\right)^{2}+\left(\frac{7}{236}\right)^{2}+(0.0112)^{2}}
$$

where: $2 \sigma_{U}$ is the two sigma uncertainty of $M_{U}$ (defined above), $\sigma_{\mathrm{T}}$ is the counting statistics uncertainty for $\mathrm{C}_{\mathrm{T}}$ (defined above), $\sigma_{\mathrm{C}}$ is the counting statistics uncertainty for $\mathrm{C}_{\mathrm{C}}$ (defined above), $\operatorname{SQRT}\left(\left(\sigma_{T} / \mathbf{C}_{\mathbf{T}}\right)^{2}+\left(\sigma_{\mathrm{C}} / \mathbf{C}_{\mathbf{C}}\right)^{2}\right)$ is the counting statistics uncertainty as a fraction of the can count rate,

7/236 is the estimated uncertainty ( 1 sigma) resulting from the far-field calibration, and $\mathbf{0 . 0 1 1 2}$ is the estimated uncertainty (1 sigma) of the transmission standard.

The Deming assay value is recorded in column nine of Table 2, and the reported value is recorded in column ten. In every case the reported value is just the larger of the two (measured value $+2 \sigma$ uncertainty). By this conservative technique we were able to give an on-the-spot assay value that included uncertainty and always represented an upper limit of content. The customer requested this conservatism with no reporting uncertainty. One single precise value of HEU content was manifested for each scrap can.

\subsection{Deming Interactive Quadratic Curve Measurement}

The acquisition of the last six pairs of data in Table 1 gave us the idea to obtain an empirical curve of HEU content that internally contained the sample transmission correction. Each sample acquisition was in a fixed geometry in a constant container. Each sample residue was approximately constant, so that sample self-absorption was directly related to sample content. We therefore reasoned that a single calibration curve ought to be suitable to directly relate measured detection rate to HEU content.

We acquired the data for the initial Deming calibration curve using the WT20xyAic data listed in Table 1. The data are the in-can data of Table 1, where in each acquisition the xy values denote the integer values that identify the standard. These standards are listed and identified in Table 3. In Table 3 we also list the measured cps for each spectrum as well as the known HEU content for each sample. The data of Table 3 are plotted in Figure 6 along with the quadratic best fit to the data. This analysis technique is also described and used in references 3 and 6 . 
Table 3. Initial Deming Data.

\begin{tabular}{|l|l|r|r|r|r|r|}
\hline Source & \multicolumn{1}{|c|}{ Mass U-235 } & $\begin{array}{c}\text { Gross } \\
\mathbf{1 8 5} \mathbf{~ K e V}\end{array}$ & $\begin{array}{c}\text { Net Area } \\
\mathbf{1 8 5} \mathbf{~ K e V}\end{array}$ & $\mathbf{1} \sigma$ & $\begin{array}{c}\text { Count } \\
\text { Time (s) }\end{array}$ & \multicolumn{1}{c|}{ cps } \\
\hline WT2023Aic & 0.69 g inside the std can & 1319 & 932 & 31 & 600 & 1.55 \\
\hline WT2021Aic & 4.20 g inside the std can & 6157 & 5538 & 78 & 600 & 9.230 \\
\hline WT2014Aic & 1.01 g inside the std can & 1738 & 1319 & 37 & 600 & 2.198 \\
\hline WT2016Aic & 39.11 g inside the std can & 36582 & 34370 & 200 & 600 & 57.283 \\
WT2019Aic & 15.67 g inside the std can & 18952 & 17359 & 141 & 600 & 28.932 \\
\hline WT2026Aic & $98.31 \mathrm{~g}$ inside the std can & 34600 & 31708 & 193 & 300 & 105.69 \\
\hline WT2022Aic & $9.90 \mathrm{~g}$ inside the std can & 2500 & 2477 & 55 & 144 & 17.20 \\
\hline
\end{tabular}

The data in Table 3 and Figure 6 represent the initial acquisition of this Deming interactive fit curve. We reacquired data to obtain an updated curve on four occasions while assaying scrap cans in the time frame from April 2000 to June 2001. We do not present these calibration curves, but note that the data are shown in blocks of acquisitions in Table 2 dated 8 August 2000, 23 August 2000, 31 October 2000, and 4 June 2001.

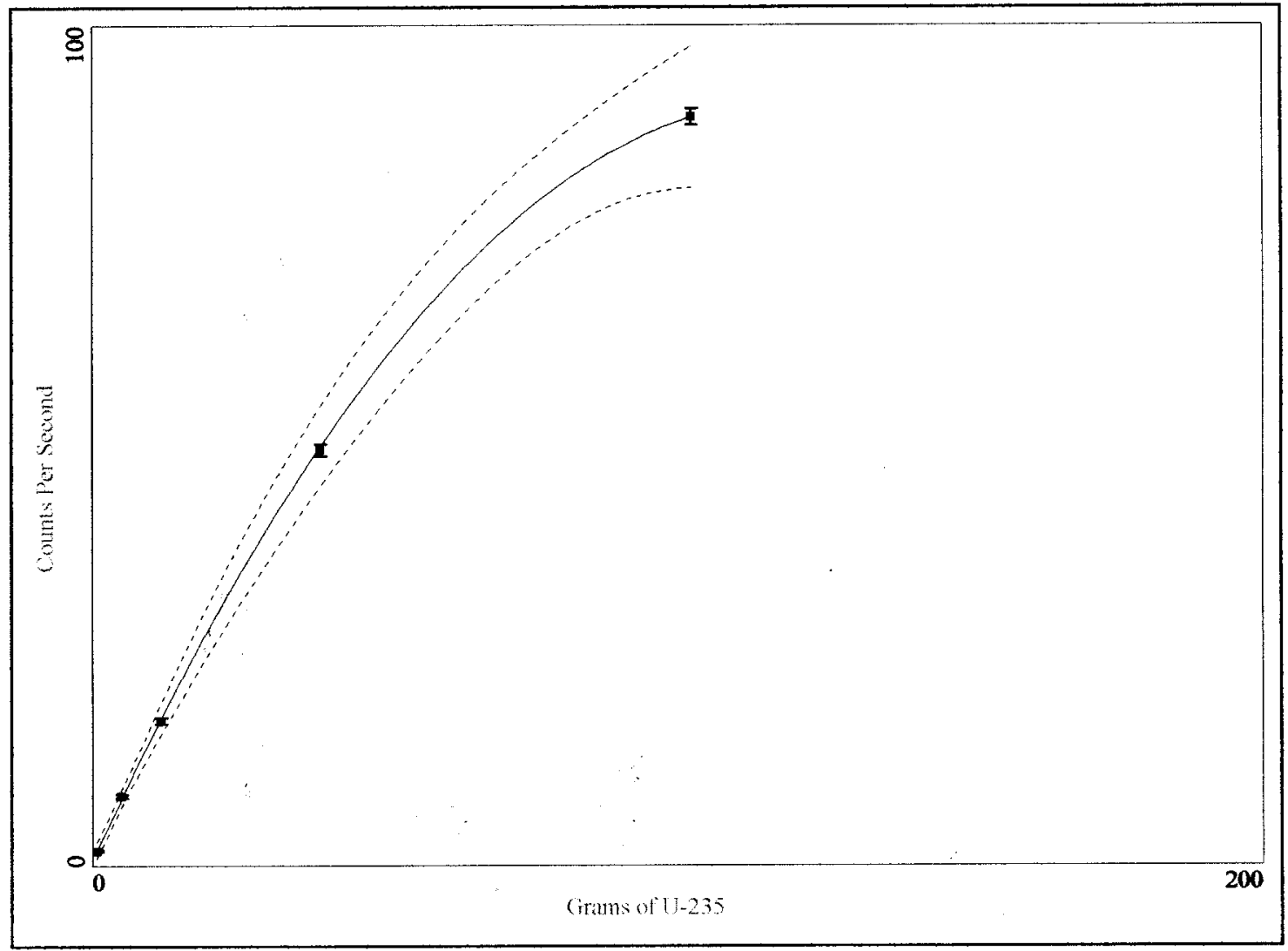

Figure 6. Deming Calibration Curve Used to Obtain ${ }^{235} \mathrm{U}$ Gram Value. 
WSRC-TR-2001-00084

Revision 0

December 18, 2001

Page 16 of 32

Table 2. Measured sample and transmission data for the 321-M scrap cans assayed for HEU content in this report.

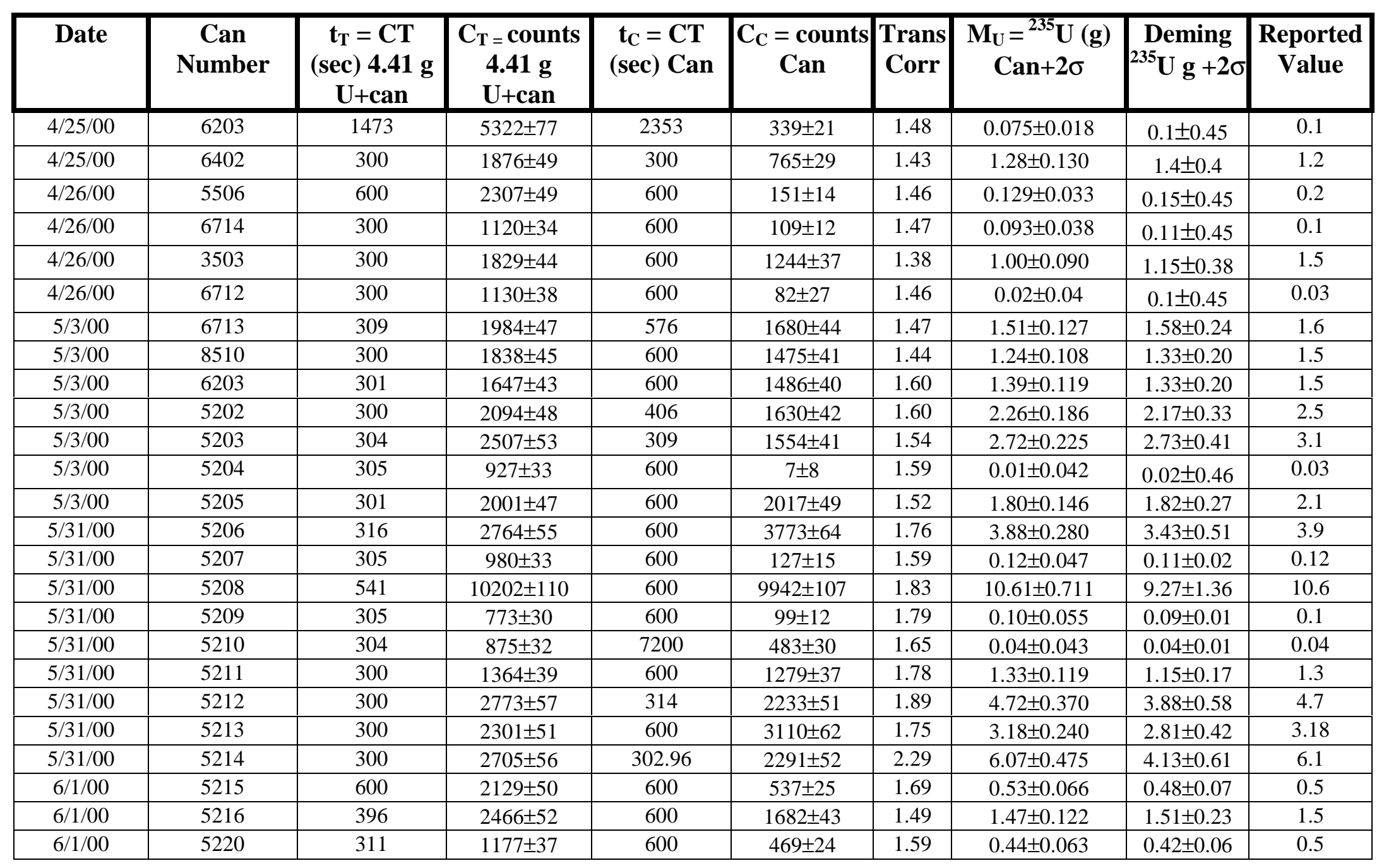


WSRC-TR-2001-00084

Revision 0

December 18, 2001

Page 17 of 32

\begin{tabular}{|c|c|c|c|c|c|c|c|c|c|}
\hline Date & $\begin{array}{c}\text { Can } \\
\text { Number }\end{array}$ & $\begin{array}{c}\mathbf{t}_{\mathrm{T}}=\mathrm{CT} \\
(\mathrm{sec}) 4.41 \mathrm{~g} \\
\mathrm{U}+\mathrm{can}\end{array}$ & $\begin{array}{c}\mathrm{C}_{\mathrm{T}}=\text { counts } \\
\mathbf{4 . 4 1} \mathrm{g} \\
\mathrm{U}+\mathrm{can}\end{array}$ & $\begin{array}{c}\mathbf{t}_{\mathrm{C}}=\mathrm{CT} \\
(\mathrm{sec}) \mathrm{Can}\end{array}$ & $\begin{array}{c}\mathrm{C}_{\mathrm{C}}=\text { counts } \\
\text { Can }\end{array}$ & $\begin{array}{l}\text { Trans } \\
\text { Corr }\end{array}$ & $\begin{array}{c}M_{U}={ }^{235} U(g) \\
\text { Can+2 } \sigma\end{array}$ & \begin{tabular}{|c|} 
Deming \\
${ }^{235} \mathrm{U} g+2 \sigma$
\end{tabular} & $\begin{array}{c}\text { Reported } \\
\text { Value }\end{array}$ \\
\hline $7 / 6 / 00$ & 706canBKG & & & 300 & $80 \pm 18$ & & & & \\
\hline $7 / 6 / 00$ & ic2021 & 300 & $2492 \pm 53$ & & & & & $4.55 \pm 0.68$ & \\
\hline $7 / 6 / 00$ & stdcanT & 300 & $902 \pm 33$ & 300 & $80 \pm 18$ & 1.67 & $0.16 \pm 0.083$ & & \\
\hline $7 / 6 / 00$ & To & 300 & $2210 \pm 50$ & & & & & & \\
\hline $7 / 6 / 00$ & wt2015 & 300 & $5637 \pm 81$ & 300 & $4862 \pm 72$ & 1.72 & $9.77 \pm 0.691$ & $10 \pm 1$ & \\
\hline $7 / 6 / 00$ & 5305 & 300 & $686 \pm 29$ & 300 & $520 \pm 29$ & 3.71 & $2.26 \pm 0.310$ & $0.96 \pm 0.38$ & 2.3 \\
\hline $7 / 6 / 00$ & 5306 & 300 & $1259 \pm 37$ & 300 & $703 \pm 30$ & 2.03 & $1.67 \pm 0.182$ & $1.40 \pm 0.11$ & 1.7 \\
\hline $7 / 6 / 00$ & 5307 & 300 & $1346 \pm 39$ & 600 & $1465 \pm 42$ & 1.93 & $1.65 \pm 0.147$ & $1.49 \pm 0.12$ & 1.7 \\
\hline $7 / 6 / 00$ & 5308 & 300 & $1528 \pm 42$ & 300 & $791 \pm 29$ & 1.76 & $1.63 \pm 0.162$ & $1.61 \pm 0.13$ & 1.7 \\
\hline $7 / 6 / 00$ & 5309 & 300 & $1198 \pm 37$ & 600 & $1427 \pm 41$ & 2.17 & $1.81 \pm 0.162$ & $1.32 \pm 0.37$ & 1.9 \\
\hline $7 / 6 / 00$ & 5310 & 300 & $1254 \pm 38$ & 600 & $1899 \pm 47$ & 2.74 & $3.04 \pm 0.252$ & $1.76 \pm 0.36$ & 3.2 \\
\hline $7 / 12 / 00$ & 712ToQC & 323 & $2287 \pm 54$ & & & & & & \\
\hline $7 / 12 / 00$ & stdcanT712 & 300 & $892 \pm 32$ & & & & & & \\
\hline $7 / 12 / 00$ & 712canBKG & 300 & & & $80 \pm 22$ & & & & \\
\hline $7 / 12 / 00$ & 5311 & 300 & $5625 \pm 83$ & 300 & $4783 \pm 79$ & 1.65 & $9.22 \pm 0.659$ & $9.63 \pm 1.22$ & 9.9 \\
\hline $7 / 12 / 00$ & 5312 & 300 & $9598 \pm 111$ & 300 & $8734 \pm 105$ & 1.63 & $16.62 \pm 1.127$ & $19.19 \pm 1.5$ & 20.7 \\
\hline $7 / 12 / 00$ & 5313 & 600 & $17283 \pm 145$ & 3600 & $93093 \pm 343$ & 1.61 & $14.59 \pm 0.932$ & $16.86 \pm 1.13$ & 18.0 \\
\hline $7 / 12 / 00$ & 5314 & 300 & $11157 \pm 124$ & 300 & $10148 \pm 118$ & 1.51 & $17.86 \pm 1.207$ & $22.67 \pm 1.75$ & 24.2 \\
\hline $7 / 12 / 00$ & WT2021ic & & & 300 & $2580 \pm 54$ & & & & \\
\hline $7 / 12 / 00$ & WT2019b & 100 & $2904 \pm 59$ & 100 & $2576 \pm 58$ & 1.52 & $13.78 \pm 1.072$ & $22.67 \pm 1.75$ & \\
\hline $7 / 12 / 00$ & $5314 \mathrm{~b}$ & 100 & $3649 \pm 73$ & 100 & $3356 \pm 69$ & 1.61 & $18.99 \pm 1.435$ & $22.67 \pm 1.75$ & 24.2 \\
\hline $7 / 12 / 00$ & 5315(F Cart) & 300 & $26516 \pm 186$ & 300 & $25883 \pm 183$ & 1.90 & $57.53 \pm 3.737$ & $78.74 \pm 9.32$ & 88 \\
\hline $7 / 12 / 00$ & 5316 & 300 & $12293 \pm 124$ & 300 & $11523 \pm 120$ & 1.72 & $23.22 \pm 1.550$ & $26.17 \pm 2.03$ & 28.2 \\
\hline $7 / 12 / 00$ & 5317 & 300 & $4088 \pm 71$ & 300 & $3176 \pm 63$ & 1.58 & $5.88 \pm 0.440$ & $6.59 \pm 0.53$ & 7.1 \\
\hline $7 / 12 / 00$ & 712ToQC1 & 100 & $710 \pm 28$ & & & & & & \\
\hline
\end{tabular}


WSRC-TR-2001-00084

Revision 0

December 18, 2001

Page 18 of 32

\begin{tabular}{|c|c|c|c|c|c|c|c|c|c|}
\hline Date & $\begin{array}{c}\text { Can } \\
\text { Number }\end{array}$ & $\begin{array}{c}t_{T}=C T \\
(\mathrm{sec}) 4.41 \mathrm{~g} \\
\mathrm{U}+\mathrm{can}\end{array}$ & $\begin{array}{c}\mathrm{C}_{\mathrm{T}}=\text { counts } \\
\mathbf{4 . 4 1} \mathrm{g} \\
\mathrm{U}+\mathrm{can}\end{array}$ & $\begin{array}{c}\mathbf{t}_{\mathrm{C}}=\mathbf{C T} \\
(\mathrm{sec}) \mathrm{Can}\end{array}$ & $\begin{array}{c}\mathrm{C}_{\mathrm{C}}=\text { counts } \\
\text { Can }\end{array}$ & $\begin{array}{l}\text { Trans } \\
\text { Corr }\end{array}$ & $\begin{array}{c}\mathbf{M}_{\mathbf{U}}={ }^{235} \mathrm{U}(\mathrm{g}) \\
\mathrm{Can}+2 \sigma\end{array}$ & \begin{tabular}{|} 
Deming \\
${ }^{235} \mathrm{U} \mathrm{g}+2 \sigma$
\end{tabular} & $\begin{array}{c}\text { Reported } \\
\text { Value }\end{array}$ \\
\hline $8 / 8 / 00$ & 88canBKG & 300 & $78 \pm 21$ & 0.26 & 0.07 & & & & \\
\hline $8 / 8 / 00$ & 88 ic2021 & 300 & $2408 \pm 56$ & 7.77 & 0.2 & & & & \\
\hline $8 / 8 / 00$ & 88 ic2016 & 178.4 & $8198 \pm 102$ & & & & & & \\
\hline $8 / 8 / 00$ & $88 \mathrm{ic} 2019$ & 238.8 & $6293 \pm 88$ & & & & & & \\
\hline $8 / 8 / 00$ & $88 \mathrm{ic} 2015$ & 300 & $4673 \pm 80$ & & & & & & \\
\hline $8 / 8 / 00$ & $88 \mathrm{ic} 2023$ & 300 & $429 \pm 31$ & & & & & & \\
\hline $8 / 8 / 00$ & $88 \mathrm{ic} 2026$ & 153 & $14494 \pm 135$ & & & & & & \\
\hline $8 / 8 / 00$ & 2021canT & 300 & $1026 \pm 40$ & & & & & & \\
\hline $8 / 8 / 00$ & $2021 \mathrm{~T}$ & 300 & $2243 \pm 52$ & 300 & $1026 \pm 40$ & & & & \\
\hline $8 / 8 / 00$ & 5402 & 300 & $5734 \pm 83$ & 300 & $4776 \pm 77$ & 1.51 & $8.07 \pm 0.575$ & $10.55 \pm 2.56$ & 13 \\
\hline $8 / 8 / 00$ & 5403 & 300 & $1522 \pm 43$ & 300 & $441 \pm 23$ & 1.42 & $0.70 \pm 0.090$ & $0.93 \pm 0.24$ & 1.2 \\
\hline $8 / 8 / 00$ & 5404 & 300 & $11402 \pm 126$ & 300 & $10518 \pm 119$ & 1.57 & $18.51 \pm 1.246$ & $24.6 \pm 6$ & 31 \\
\hline $8 / 8 / 00$ & 5404 & 300 & $11402 \pm 126$ & 300 & $10335 \pm 118$ & 1.43 & $16.55 \pm 1.116$ & $24.75 \pm 6.05$ & \\
\hline $8 / 8 / 00$ & 5408 & 138.2 & $3673 \pm 68$ & 246.7 & $5657 \pm 84$ & 1.41 & $10.88 \pm 0.762$ & $15.5 \pm 3.8$ & 19.3 \\
\hline $8 / 8 / 00$ & 5409 & 300 & $5304 \pm 81$ & 300 & $4196 \pm 74$ & 1.40 & $6.60 \pm 0.479$ & $9.22 \pm 2.25$ & 11.4 \\
\hline $8 / 8 / 00$ & 5410 & 159 & $5335 \pm 85$ & 300 & $9090 \pm 112$ & 1.49 & $15.22 \pm 1.036$ & $21 \pm 5$ & 23 \\
\hline $8 / 8 / 00$ & 5405 & 118.5 & $5562 \pm 87$ & 183.3 & $8262 \pm 105$ & 1.97 & $29.93 \pm 2.045$ & $33 \pm 8$ & 36 \\
\hline $8 / 8 / 00$ & 5401 & 332.1 & $2083 \pm 50$ & 300 & $829 \pm 33$ & 1.44 & $1.34 \pm 0.138$ & $1.76 \pm 0.44$ & 2.2 \\
\hline $8 / 8 / 00$ & 5315 (Chip Comp) & 149.6 & $5609 \pm 84$ & 1800 & $60808 \pm 282$ & 1.40 & $15.89 \pm 1.019$ & $24 \pm 6$ & 26 \\
\hline $8 / 8 / 00$ & 5318 & 171.4 & $5265 \pm 79$ & 190.9 & $5309 \pm 81$ & 1.58 & $14.78 \pm 1.040$ & $18.72 \pm 2.38$ & 21 \\
\hline $8 / 8 / 00$ & 5319 & 151.04 & $5108 \pm 82$ & 156.5 & $4888 \pm 79$ & 1.68 & $17.60 \pm 1.253$ & $21.9 \pm 2.8$ & 23.6 \\
\hline $8 / 9 / 00$ & $2021 \mathrm{Tqc}$ & 300 & $2151 \pm 49$ & & & & & & \\
\hline \multicolumn{10}{|l|}{$8 / 8 / 00$} \\
\hline $8 / 8 / 00$ & $2021 \mathrm{~T}$ & 300 & $2243 \pm 52$ & 300 & $1026 \pm 40$ & 1.34 & $1.54 \pm 0.156$ & $1.91 \pm 0.36$ & \\
\hline $8 / 9 / 00$ & 5320 & 300 & $7950 \pm 101$ & 175.4 & $4189 \pm 75$ & 1.67 & $13.38 \pm 0.974$ & $15.43 \pm 1.98$ & 18 \\
\hline $8 / 8 / 00$ & 5218 & 300 & $950 \pm 34$ & 300 & $58 \pm 21$ & 1.56 & $0.10 \pm 0.083$ & $0.11 \pm 0.02$ & 0.2 \\
\hline
\end{tabular}


WSRC-TR-2001-00084

Revision 0

December 18, 2001

Page 19 of 32

\begin{tabular}{|c|c|c|c|c|c|c|c|c|c|}
\hline Date & $\begin{array}{c}\text { Can } \\
\text { Number }\end{array}$ & $\begin{array}{c}t_{\mathrm{T}}=\mathrm{CT} \\
(\mathrm{sec}) 4.41 \mathrm{~g} \\
\mathrm{U}+\mathrm{can}\end{array}$ & $\begin{array}{c}\mathrm{C}_{\mathrm{T}}=\text { counts } \\
\mathbf{4 . 4 1} \mathrm{g} \\
\mathrm{U}+\mathrm{can}\end{array}$ & $\begin{array}{l}\mathbf{T}_{\mathrm{C}}=\mathrm{CT} \\
(\mathrm{sec}) \mathrm{Can}\end{array}$ & $\begin{array}{c}\mathrm{C}_{\mathrm{C}}=\text { counts } \\
\text { Can }\end{array}$ & $\begin{array}{l}\text { Trans } \\
\text { Corr }\end{array}$ & $\begin{array}{c}M_{U}={ }^{235} U(g) \\
\text { Can }+2 \sigma\end{array}$ & \begin{tabular}{|c|} 
Deming \\
${ }^{235} \mathrm{U} g+2 \sigma$
\end{tabular} & $\begin{array}{c}\text { Reported } \\
\text { Value }\end{array}$ \\
\hline $8 / 23 / 00$ & 823 canBKG & 300 & $88 \pm 20$ & & & & & & \\
\hline $8 / 23 / 00$ & $823 \mathrm{QC} 2021$ & 300 & $2272 \pm 51$ & & & & & & \\
\hline $8 / 23 / 00$ & 823 canT & 300 & $853 \pm 32$ & & & & & & \\
\hline $8 / 23 / 00$ & 8232021To & 300 & $1898 \pm 45$ & & & & & & \\
\hline \multirow[t]{6}{*}{$8 / 23 / 00$} & 8322014 & 300 & $516 \pm 26$ & & & & & & \\
\hline & 8322016 & 300 & $14572 \pm 136$ & & & & & & \\
\hline & 8322015 & 149.6 & $2164 \pm 52$ & & & & & & \\
\hline & 8322026 & 55.4 & $4458 \pm 78$ & & & & & & \\
\hline & 8322019 & 300 & $7196 \pm 95$ & & & & & & \\
\hline & $8322021 \mathrm{a}$ & 300 & $2328 \pm 52$ & & & & & & \\
\hline $8 / 23 / 00$ & $5501 \mathrm{a}$ & 130.36 & $6060 \pm 89$ & 165.1 & $7064 \pm 99$ & 1.40 & $21.07 \pm 1.46$ & $32.43 \pm 4.16$ & \\
\hline $8 / 23 / 00$ & 5502 & 156.1 & $7495 \pm 98$ & 300 & $13370 \pm 133$ & 1.45 & $22.73 \pm 1.51$ & $34.43 \pm 4.77$ & 36.4 \\
\hline $8 / 23 / 00$ & $5502 \mathrm{~T} 1$ & 130.36 & $6060 \pm 89$ & 82.4 & $3520 \pm 67$ & 1.39 & $20.84 \pm 1.54$ & & \\
\hline $8 / 23 / 00$ & 5503 & 85.32 & $2524 \pm 56$ & 75.9 & $1969 \pm 51$ & 1.42 & $12.88 \pm 1.06$ & $16.91 \pm 2.07$ & 18 \\
\hline $8 / 23 / 00$ & 5504 & 181 & $1036 \pm 37$ & 300 & $864 \pm 34$ & 1.60 & $1.62 \pm 0.12$ & $1.62 \pm 0.28$ & 2 \\
\hline $8 / 23 / 00$ & 5411 & 105.8 & $1781 \pm 49$ & 150.02 & $1991 \pm 50$ & 1.43 & $6.66 \pm 0.54$ & $7.92 \pm 1.21$ & 9.4 \\
\hline $8 / 23 / 00$ & 5412 & 300 & $1774 \pm 46$ & 300 & $1034 \pm 38$ & 1.72 & $2.08 \pm 0.20$ & $1.94 \pm 0.34$ & 2.4 \\
\hline $8 / 23 / 00$ & 8235501 & 159.9 & $6992 \pm 96$ & 300 & $12235 \pm 128$ & 1.57 & $22.51 \pm 1.50$ & $30.27 \pm 3.63$ & 34.6 \\
\hline $8 / 28 / 00$ & 5416 & 264.2 & $3935 \pm 75$ & 300 & $3599 \pm 71$ & 1.53 & $6.42 \pm 0.48$ & $6.66 \pm 0.50$ & 7.2 \\
\hline $8 / 28 / 00$ & 5417 & 233.3 & $4034 \pm 76$ & 287.24 & $3927 \pm 75$ & 1.36 & $6.54 \pm 0.48$ & $7.67 \pm 0.57$ & 8.2 \\
\hline
\end{tabular}


WSRC-TR-2001-00084

Revision 0

December 18, 2001

Page 20 of 32

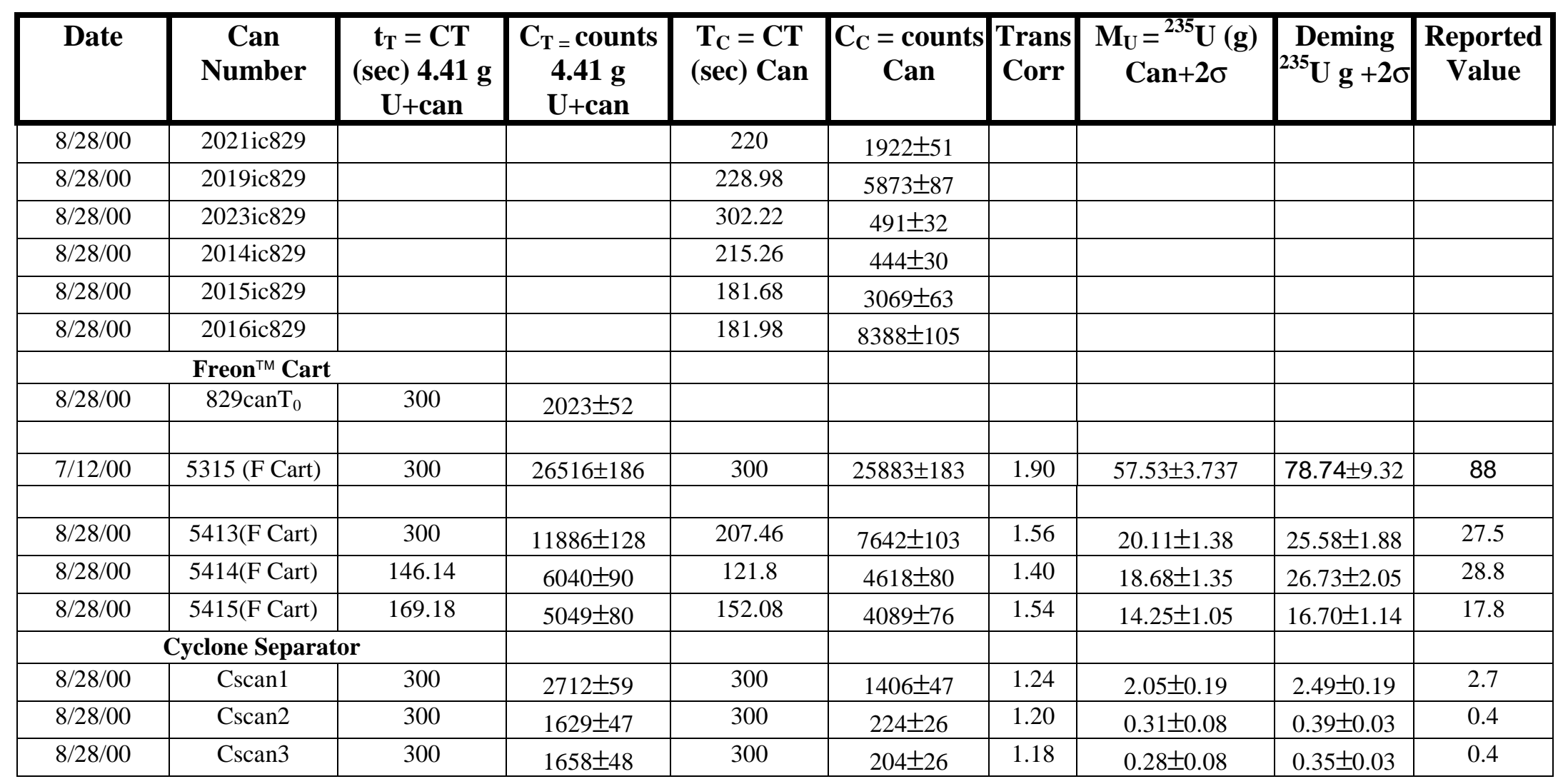


WSRC-TR-2001-00084

Revision 0

December 18, 2001

Page 21 of 32

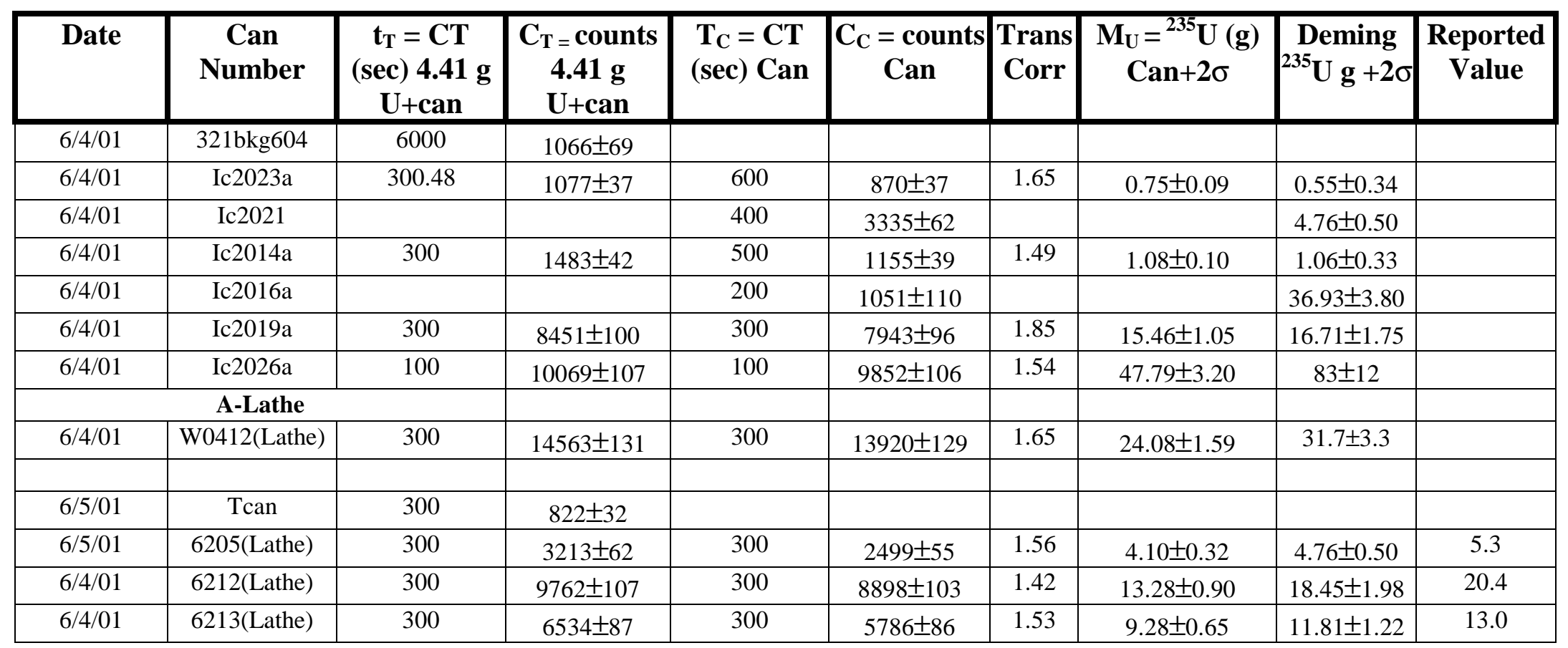


WSRC-TR-2001-00084

Revision 0

December 18, 2001

Page 22 of 32

\begin{tabular}{|c|c|c|c|c|c|c|c|c|c|}
\hline Date & $\begin{array}{c}\text { Can } \\
\text { Number }\end{array}$ & $\begin{array}{c}\mathbf{t}_{\mathrm{T}}=\mathrm{CT} \\
(\mathrm{sec}) 4.41 \mathrm{~g} \\
\mathrm{U}+\mathrm{can}\end{array}$ & $\begin{array}{c}\mathrm{C}_{\mathrm{T}}=\text { counts } \\
\mathbf{4 . 4 1} \mathrm{g} \\
\mathrm{U}+\mathrm{can}\end{array}$ & $\begin{array}{l}\mathbf{T}_{\mathrm{C}}=\mathrm{CT} \\
(\mathrm{sec}) \mathrm{Can}\end{array}$ & $\begin{array}{c}\mathrm{C}_{\mathrm{C}}=\text { counts } \\
\text { Can }\end{array}$ & $\begin{array}{c}\text { Trans } \\
\text { Corr }\end{array}$ & $\begin{array}{c}M_{U}={ }^{235} U(g) \\
C a n+2 \sigma\end{array}$ & $\begin{array}{c}\text { Deming } \\
{ }^{235} \mathrm{U} g+2 \sigma\end{array}$ & $\begin{array}{l}\text { Reported } \\
\text { Value }\end{array}$ \\
\hline $10 / 31 / 00$ & STDcan & 500 & $1711 \pm 51$ & & & & & & \\
\hline $10 / 31 / 00$ & $2022 \mathrm{ic}$ & 144 & $2477 \pm 55$ & & & & & & \\
\hline $10 / 31 / 00$ & $2023 \mathrm{ic}$ & 200.3 & $347 \pm 25$ & & & & & & \\
\hline $10 / 31 / 00$ & 2021ic & 170.28 & $1414 \pm 42$ & & & & & & \\
\hline $10 / 31 / 00$ & 2026ic & 122.86 & $10963 \pm 117$ & & & & & & \\
\hline $10 / 31 / 00$ & $2016 \mathrm{ic}$ & 135.26 & $6698 \pm 92$ & & & & & & \\
\hline $10 / 31 / 00$ & canbkg1031 & 1839 & $292 \pm 53$ & & & & & & \\
\hline $10 / 31 / 00$ & 5101 & 178.74 & $1300 \pm 43$ & 300 & $1254 \pm 44$ & 1.48 & $2.169 \pm 0.213$ & $2.7 \pm 0.4$ & 3.1 \\
\hline $10 / 31 / 00$ & 5103 & 300 & $14915 \pm 140$ & 225.4 & $10668 \pm 117$ & 1.68 & $27.96 \pm 1.876$ & $35.3 \pm 5.5$ & 41 \\
\hline $10 / 31 / 00$ & 3503 & 300 & $1528 \pm 45$ & 300 & $580 \pm 33$ & 1.46 & $0.99 \pm 0.133$ & $1.22 \pm 0.19$ & 1.4 \\
\hline $10 / 31 / 00$ & 5302 & 300 & $21904 \pm 167$ & 197.12 & $14138 \pm 134$ & 2.29 & $57.63 \pm 3.814$ & $62.53 \pm 10.84$ & 73 \\
\hline $11 / 1 / 00$ & 5105 & 300 & $1643 \pm 47$ & 300 & $664 \pm 34$ & 1.44 & $1.12 \pm 0.138$ & $1.4 \pm 0.2$ & 1.8 \\
\hline $11 / 1 / 00$ & 5102 & 174.62 & $1582 \pm 46$ & 300 & $1827 \pm 51$ & 1.51 & $3.23 \pm 0.274$ & $3.9 \pm 0.6$ & 4.5 \\
\hline $11 / 1 / 00$ & 5104 & 300 & $16262 \pm 148$ & 139.44 & $7075 \pm 98$ & 1.40 & $24.87 \pm 1.721$ & $38.59 \pm 5.99$ & 44 \\
\hline $11 / 1 / 00$ & 5303 & 300 & $1415 \pm 45$ & 300 & $605 \pm 32$ & 1.58 & $1.12 \pm 0.143$ & $1.28 \pm 0.2$ & 1.5 \\
\hline $11 / 1 / 00$ & 5304 & 263.3 & $1715 \pm 49$ & 300 & $1067 \pm 39$ & 1.51 & $1.89 \pm 0.185$ & $2.27 \pm 0.36$ & 2.6 \\
\hline $11 / 2 / 00$ & 5201 & 154.1 & $440 \pm 26$ & 300 & $56 \pm 20$ & 1.59 & $0.10 \pm 0.100$ & $0.12 \pm 0.02$ & 0.2 \\
\hline $11 / 2 / 00$ & 5217 & 102 & $1566 \pm 44$ & 166.68 & $2069 \pm 53$ & 1.52 & $6.61 \pm 0.540$ & $8.12 \pm 1.28$ & 9.4 \\
\hline $11 / 2 / 00$ & 5219 & 206.1 & $1046 \pm 37$ & 300 & $486 \pm 32$ & 1.40 & $0.80 \pm 0.121$ & $1.03 \pm 0.16$ & 1.2 \\
\hline $11 / 2 / 00$ & 5421 & 139.56 & $3153 \pm 66$ & 74.22 & $1448 \pm 44$ & 1.48 & $10.14 \pm 0.891$ & $13.06 \pm 2.05$ & 15.1 \\
\hline $11 / 2 / 00$ & 5418 & 155.86 & $487 \pm 28$ & 300 & $50 \pm 21$ & 1.51 & $0.09 \pm 0.096$ & $0.11 \pm 0.02$ & 0.2 \\
\hline
\end{tabular}


WSRC-TR-2001-00084

Revision 0

December 18, 2001

Page 23 of 32

\begin{tabular}{|c|c|c|c|c|c|c|c|c|c|}
\hline Date & $\begin{array}{c}\text { Can } \\
\text { Number }\end{array}$ & $\begin{array}{c}\mathbf{t}_{\mathrm{T}}=\mathrm{CT} \\
(\mathrm{sec}) 4.41 \mathrm{~g} \\
\mathrm{U}+\mathrm{can}\end{array}$ & $\begin{array}{c}\mathrm{C}_{\mathrm{T}}=\text { counts } \\
\mathbf{4 . 4 1} \mathrm{g} \\
\mathrm{U}+\mathrm{can} \\
\end{array}$ & $\begin{array}{l}\mathbf{T}_{\mathrm{C}}=\mathrm{CT} \\
(\mathrm{sec}) \mathrm{Can}\end{array}$ & $\begin{array}{c}\mathrm{C}_{\mathrm{C}}=\text { counts } \\
\text { Can }\end{array}$ & $\begin{array}{l}\text { Trans } \\
\text { Corr }\end{array}$ & $\begin{array}{c}M_{U}={ }^{235} U(g) \\
C a n+2 \sigma\end{array}$ & $\begin{array}{c}\text { Deming } \\
{ }^{235} \mathrm{U} g+2 \sigma\end{array}$ & $\begin{array}{c}\text { Reported } \\
\text { Value }\end{array}$ \\
\hline $1 / 10 / 01$ & 0110BKG & 1800 & $247 \pm 29$ & & & & & & \\
\hline $1 / 10 / 01$ & 5221 & 300 & $3676 \pm 67$ & 300 & $2671 \pm 51$ & 1.50 & $4.69 \pm 0.56$ & $5.12 \pm 0.63$ & 4.7 \\
\hline $1 / 10 / 01$ & 5106 & 300 & $21138 \pm 165$ & 300 & $20318 \pm 162$ & 1.66 & $39.49 \pm 2.58$ & & 38.8 \\
\hline $1 / 10 / 01$ & 5507 & 300 & $9679 \pm 108$ & 300 & $9001 \pm 104$ & 1.83 & $19.24 \pm 1.30$ & $20.7 \pm 2.62$ & 18.8 \\
\hline $1 / 10 / 01$ & 5508 & 300 & $5848 \pm 85$ & 300 & $4731 \pm 76$ & 1.42 & $7.88 \pm 0.56$ & $9.51 \pm 1.21$ & 7.7 \\
\hline $1 / 10 / 01$ & 5302 & 300 & $8298 \pm 98$ & 300 & $6077 \pm 96$ & 1.01 & $7.18 \pm 0.51$ & $12.67 \pm 1.63$ & 9.8 \\
\hline $1 / 10 / 01$ & qc011001 & 300 & $2265 \pm 53$ & & & & & & \\
\hline $1 / 16 / 01$ & 11601canBKG & 1800 & $809 \pm 40$ & & & & & & \\
\hline $1 / 16 / 01$ & 11601QC2021 & 300 & $2167 \pm 50$ & & & & & & \\
\hline $1 / 16 / 01$ & 5506 & 300 & $1229 \pm 37$ & 300 & $70 \pm 9$ & 1.43 & $0.12 \pm 0.04$ & $0.14 \pm 0.45$ & 0.1 \\
\hline $1 / 16 / 01$ & 5419 & 300 & $1787 \pm 46$ & 300 & $720 \pm 30$ & 1.49 & $1.25 \pm 0.13$ & $1.34 \pm 0.37$ & 1.2 \\
\hline $1 / 16 / 01$ & 5107 & 300 & $8018 \pm 99$ & 300 & $6726 \pm 92$ & 1.35 & $10.63 \pm 0.73$ & $14.29 \pm 1.83$ & 11.4 \\
\hline $1 / 16 / 01$ & 5505 & 300 & $1907 \pm 47$ & 300 & $876 \pm 33$ & 1.51 & $1.55 \pm 0.16$ & $1.63 \pm 0.36$ & 1.5 \\
\hline $1 / 16 / 01$ & 5420 & 300 & $5454 \pm 82$ & 300 & $4591 \pm 74$ & 1.65 & $8.87 \pm 0.63$ & $9.20 \pm 1.16$ & 8.6 \\
\hline $1 / 16 / 01$ & 6008 & 300 & $1140 \pm 36$ & 300 & $36 \pm 7$ & 1.46 & $0.06 \pm 0.04$ & $0.08 \pm 0.45$ & 0.1 \\
\hline $1 / 16 / 01$ & 11601QC2021b & 300 & $2144 \pm 50$ & & & & & & \\
\hline & & & & & & & & & \\
\hline & & & & & & & & & \\
\hline & & & & & & & & & \\
\hline & & & & & & & & & \\
\hline
\end{tabular}


WSRC-TR-2001-00084

Revision 0

December 18, 2001

Page 24 of 32

\begin{tabular}{|c|c|c|c|c|c|c|c|c|c|}
\hline Date & $\begin{array}{c}\text { Can } \\
\text { Number }\end{array}$ & $\begin{array}{c}\mathbf{t}_{\mathrm{T}}=\mathrm{CT} \\
(\mathrm{sec}) 4.41 \mathrm{~g} \\
\mathrm{U}+\mathrm{can}\end{array}$ & $\begin{array}{c}\mathrm{C}_{\mathrm{T}}=\text { counts } \\
\mathbf{4 . 4 1} \mathrm{g} \\
\mathrm{U}+\mathrm{can}\end{array}$ & $\begin{array}{l}\mathbf{T}_{\mathrm{C}}=\mathrm{CT} \\
(\mathrm{sec}) \mathrm{Can}\end{array}$ & $\begin{array}{c}\mathrm{C}_{\mathrm{C}}=\text { counts } \\
\text { Can }\end{array}$ & $\begin{array}{c}\text { Trans } \\
\text { Corr }\end{array}$ & $\begin{array}{c}M_{U}={ }^{235} U(g) \\
C a n+2 \sigma\end{array}$ & $\begin{array}{c}\text { Deming } \\
{ }^{235} \mathrm{U} g+2 \sigma\end{array}$ & $\begin{array}{c}\text { Reported } \\
\text { Value }\end{array}$ \\
\hline $1 / 17 / 01$ & 11701canBKG & 600 & $254 \pm 22$ & & & & & & \\
\hline $1 / 17 / 01$ & 11701QC2021 & 300 & $2098 \pm 52$ & & & & & & \\
\hline $1 / 17 / 01$ & 6510 & 300 & $994 \pm 35$ & 300 & $141 \pm 13$ & 1.66 & $0.27 \pm 0.07$ & & \\
\hline $1 / 17 / 01$ & 6504 & 300 & $1051 \pm 37$ & 300 & $163 \pm 15$ & 1.63 & $0.31 \pm 0.07$ & & \\
\hline $1 / 17 / 01$ & 6511 & 300 & $1019 \pm 36$ & 300 & $73 \pm 9$ & 1.58 & $0.13 \pm 0.05$ & & \\
\hline $1 / 17 / 01$ & 6505 & 300 & $1132 \pm 37$ & 300 & $58 \pm 10$ & 1.48 & $0.10 \pm 0.05$ & & \\
\hline $1 / 17 / 01$ & 6503 & 300 & $1168 \pm 36$ & 300 & $71 \pm 10$ & 1.47 & $0.12 \pm 0.05$ & & \\
\hline $1 / 17 / 01$ & 6509 & 300 & $1158 \pm 36$ & 300 & $84 \pm 10$ & 1.48 & $0.15 \pm 0.05$ & & \\
\hline $1 / 17 / 01$ & 6506 & 300 & $1146 \pm 37$ & 300 & $120 \pm 12$ & 1.52 & $0.21 \pm 0.06$ & & \\
\hline $1 / 17 / 01$ & 6507 & 300 & $1166 \pm 36$ & 300 & $91 \pm 11$ & 1.48 & $0.16 \pm 0.05$ & & \\
\hline $1 / 17 / 01$ & 6508 & 300 & $1180 \pm 37$ & 300 & $72 \pm 9$ & 1.46 & $0.12 \pm 0.05$ & & \\
\hline $1 / 17 / 01$ & 6512 & 300 & $1144 \pm 36$ & 300 & $158 \pm 14$ & 1.55 & $0.29 \pm 0.06$ & & \\
\hline \multicolumn{7}{|c|}{ Sum of empty scrap cans 6503-6512 } & $\mathbf{1 . 8 7} \pm \mathbf{0 . 1 9}$ & & \\
\hline $1 / 17 / 01$ & 11701QC2021b & 300 & $2197 \pm 50$ & & & & & & \\
\hline
\end{tabular}




\section{DISCUSSION}

As shown in Table 2, most of the scrap cans we assayed contained HEU residue in the range of 0.5 to $5 \mathrm{~g}$. Most of the cans were assayed with a count time of $300 \mathrm{sec}$, for which we obtained a lower limit of content of $0.3 \mathrm{~g}^{235} \mathrm{U}$. Almost all of the transmission correction factors obtained were in the range of 1.4 to 2 . From a thorough review of Table 2, the reader can see that about $75 \%$ of the time the transmission corrected value and the Deming value agree within $2 \sigma$ uncertainty. The exceptions are always for the cans that contain bulk quantities of HEU, where we expect the accuracy for both techniques to degrade. For assay results above $20 \mathrm{~g}$, we generally accepted the Deming result. For those below $20 \mathrm{~g}$ the two techniques are in $2 \sigma$ agreement, but we believe the transmission-corrected value provides better accuracy and clearly better precision.

The good agreement between the two techniques of assay lends good support to the reliability of the two assay calculations. But there are several sets of cans that taken together provide especially interesting sets of data and results. We discuss those more thoroughly in this section. The first group is a set of cans assayed by both methods on 4 June 2001. The results for these are listed by that date on page 21 in Table 2. These assays consisted of using the standard can with four selected HEU sources of known content placed sequentially inside the can. The four were then assayed using the Deming interactive curve, and they were assayed using the transmission-correction technique of section 2.1. These are the only four "samples" where we made such a comparison using the known standards available to us.

The four standards assayed inside the standard can are wt2023a, wt2014a, wt2019a, and wt2026a, which have HEU contents of $0.69 \mathrm{~g}, 1.01 \mathrm{~g}, 15.78 \mathrm{~g}$, and $98.38 \mathrm{~g}$ respectively. We have listed the results for the standards in Table 4 below. Note the assayed values for the first three by both techniques have excellent agreement with the known standards. The assay value for the fourth standard (wt2026a) had poor agreement with the known content because it is a lump sample. Transmission-correction assays by $\gamma$-PHA for lump samples are widely accepted by the NDA community to yield results that are biased low. However the results for Table 4 demonstrate the utility of our assay methods in the range of $0.6 \mathrm{~g} \mathrm{HEU}$ to $16 \mathrm{~g}$ HEU.

Table 4. Reported Values for Assay of HEU Standards by Both Techniques.

\begin{tabular}{|c|c|c|c|}
\hline $\begin{array}{c}\text { Source } \\
\text { ID }\end{array}$ & $\begin{array}{c}{ }^{235} \mathbf{U} \\
\text { Mass (g) }\end{array}$ & $\begin{array}{c}\text { Assay Result } \\
(\mathbf{g})\end{array}$ & $\begin{array}{c}\text { Deming } \\
\text { Result (g) }\end{array}$ \\
\hline wt2023a & 0.69 & $0.75 \pm 0.09$ & $0.55 \pm 0.34$ \\
\hline wt2014a & 1.01 & $1.08 \pm 0.1$ & $1.06 \pm 0.5$ \\
\hline wt2019a & 15.78 & $15.46 \pm 1.05$ & $16.71 \pm 1.75$ \\
\hline wt2026a & 98.38 & $47.79 \pm 3.2$ & $83 \pm 12$ \\
\hline
\end{tabular}


The next group of scrap cans we discuss is a set of four that were filled with HEU residue obtained in the decontamination of the 321-M A-Lathe. ${ }^{7}$ These four cans were assayed on 4 June 2001 and are listed by that date on page 21 in Table 2. We believe the assay results for these four cans represents some of the strongest support for the accuracy of our methods that we present in this report. We refer to scrap cans w0412, 6205, 6212, and 6213 in Table 2.

Scrap can w0412 was filled with HEU residue recovered from the decontamination of the 321-M A-lathe and was placed in 55-gallon drum FD2189 along with job control material from the decontamination work. Drum FD2189 was assayed on the 313-M Q ${ }^{2}$ assay instrument in May 2001, and the measured content was $24 \pm 14 \mathrm{~g}$ HEU. Subsequently drum FD2189 was opened, and scrap can w0412 was removed. The drum was re-sealed and re-assayed with the resulting content of $0.3 \pm 0.2 \mathrm{~g} \mathrm{HEU}$. We conclude the $24 \pm 14 \mathrm{~g}$ from the $\mathrm{Q}^{2}$ assay came almost entirely from can w0412. ${ }^{7}$

Scrap can w0412 was then assayed on the far field scrap can assay station of this report. As seen in Table 2, the transmission corrected result was $24.08 \pm 1.59 \mathrm{~g}$, and the Deming result was $31.7 \pm 3.3 \mathrm{~g}$. Both results are in good agreement with the $\mathrm{Q}^{2}$ result and are in fairly good mutual agreement. The measured transmission correction factor was 1.65.

Because can w0412 contained more than $20 \mathrm{~g}$ of HEU, we repacked its contents into three cans with the intention to assay the three cans each within the range of 0 to $15 \mathrm{~g}$ HEU. The contents were packed into cans 6205, 6212, and 6213, and each was assayed on the far field station. As seen in Table 2, the results provide extremely good support for the original measurement of can w0412 and are in very good mutual agreement.

Finally to emphasize this point even more, each of the cans 6205,6212 , and 6213 were placed into separate 55-gallon drums and were assayed again. The results are reported in Table 5 of reference 7 and are $3 \pm 2 \mathrm{~g}, 10 \pm 6 \mathrm{~g}$, and $7 \pm 4 \mathrm{~g}$ respectively. Once again the results were in excellent agreement with the transmission-corrected assays of the far field assay station.

The third group of scrap cans we discuss is a set of four cans filled with recovered residue from the decontamination of the 321-M Freon ${ }^{\mathrm{TM}}$ cart. $^{8}$ All of the recovered residue from this decontamination was placed originally in scrap can 5315, which was assayed on 12 July 2000 as shown on pages 17 and 20 in Table 2. The transmissioncorrected result for can 5315 was $57.53 \pm 3.74 \mathrm{~g}$ with a correction factor of 1.90 , and the Deming interactive fit result was $78.74 \pm 9.32 \mathrm{~g}$. Since both of these values were out of our preferred range, the recovered residue was removed from 5315 and re-packed into three separate cans just as above for the A-lathe cans. 
These three repacked cans were assayed as cans 5413, 5414, and 5415 on 28 August 2000 and are listed on that date on page 20 in Table 2. The measured values by transmission correction were $20 \pm 1 \mathrm{~g}, 19 \pm 1 \mathrm{~g}$, and $14 \pm 1 \mathrm{~g}$; while the Deming values were $26 \pm 2 \mathrm{~g}, 27 \pm 2 \mathrm{~g}$, and $17 \pm 1 \mathrm{~g}$. Note that scrap can 5315 was subsequently filled with material from the chip compactor and re-assayed on 8 August 2000.

All six of the measured values for scrap cans $5413-5415$ are at the marginal limit of our region of accuracy, but the two values for each can agree within 30\%, and the sums agree within 24\%. Consistent with our policy to accept the Deming results for cans that assayed above $20 \mathrm{~g}$, we believe the Deming values for these four cans to represent the more accurate results, and those are the values we reported in reference 8 . These values demonstrate that approximately $70 \mathrm{~g}$ of HEU residue was recovered from the decontamination of the 321-M Freon ${ }^{\mathrm{TM}}$ cart. This value is consistent with the holdup assays reported in reference 8 before and after decontamination of the cart.

A fourth set of three cans we discuss contains the scrap cans from the cyclone separator. These three cans contain residual HEU recovered from the decontamination of the cyclone separator and are labeled CScan1, Cscan2, and Cscan3. They were assayed on 28 August and are listed by that date on page 20 in Table 2. These three cans have a geometry and container thickness different from all of the other scrap cans and from the standard can. A photograph of one of these cans is shown in Figure 7. Note the transmission correction factors for these three cans ranged from 1.18 to 1.24 , which is significantly lower than the correction factors for the larger scrap cans.

The first observation for these three cyclone separator cans is that the measured transmission correction factors are in a very small range. That is, they have extremely good precision. We believe this is a good endorsement of the assay technique. A second observation is that the measured values by the two techniques are in good mutual support. The transmission corrected results for the three cans are $2.05 \pm 0.19,0.31 \pm 0.08$, and $0.28 \pm 0.08$; and the Deming results are $2.49 \pm 0.19,0.39 \pm 0.03$, and $0.35 \pm 0.03$. Since the Deming technique was calibrated with the standard can, it is not completely applicable to these three cans. However the two techniques still yielded values in very good agreement. These three cans lend especially strong support to the transmission corrected assay technique. 


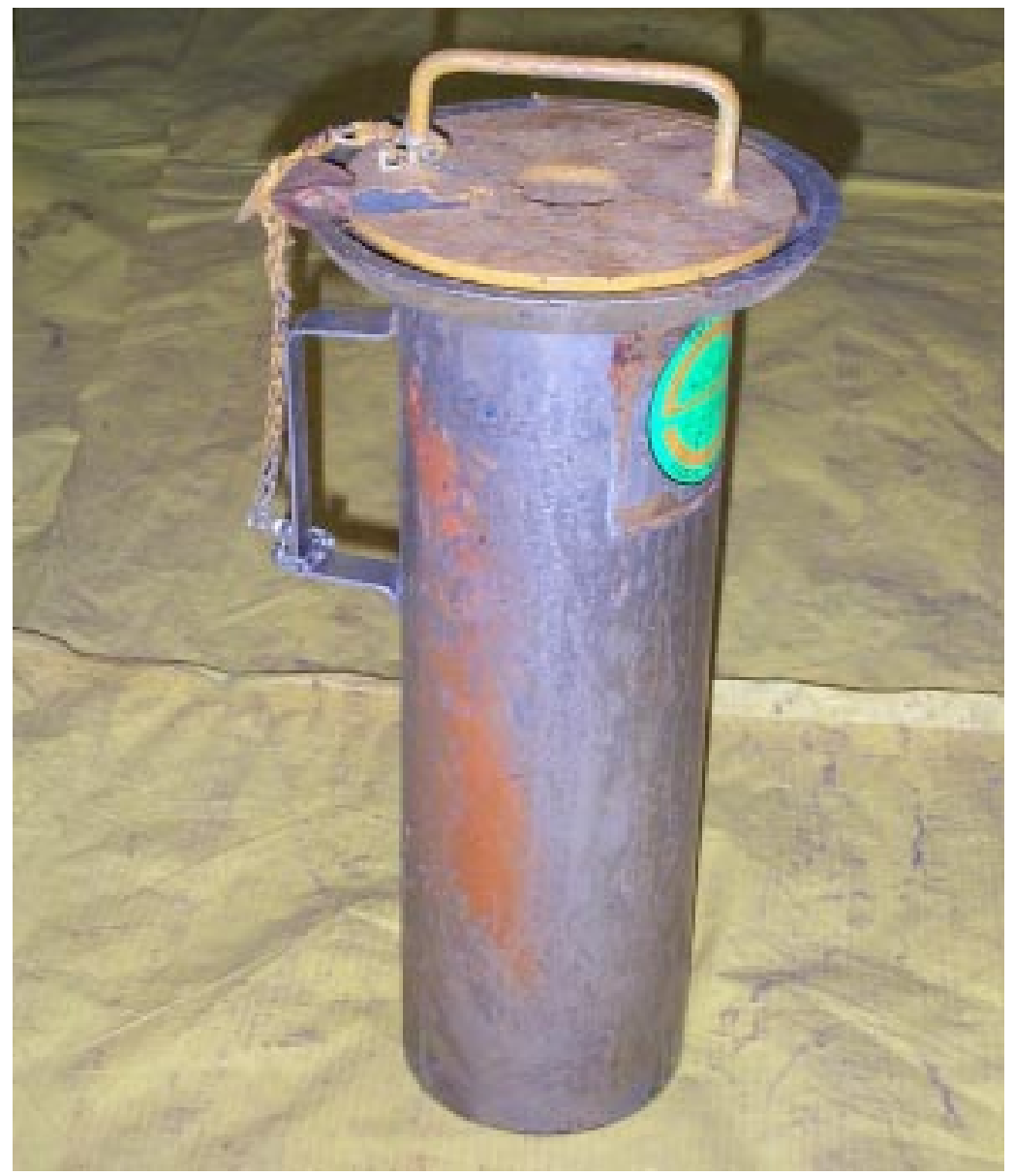

Page 28 of 32

Figure 7. A photograph of a cyclone separator can.

\section{RESULTS}

Table 5 contains a list of all of the scrap cans assayed and grouped by component whence the HEU residue came. ${ }^{9}$ In particular in Table 5 we have three groups of cans that came from the Freon ${ }^{\mathrm{TM}}$ Cart, the A-Lathe, and the Casting Room. For each of these components we have a single can that contained excessive amounts of HEU that we requested the 321-M operators to repack into multiple cans. In every case the sum of the content in the repacked cans agrees well with the assayed content in the original can even when the content of the original can was outside of our accepted calibration range.

The A-lathe and Freon cart scrap cans have already been discussed in this report. The casting room cans are numbers 5302, 5104, 5507, and 5107 as identified in Tables 2 and 5. The assayed sum in the repacked cans 5104, 5507, and 5107 matches exactly the reported content in the original casting room can 5302. Can number 5104 is identified in reference 9. It was sent to Solid Waste in B-25 container \#1883, and we are pretty sure it is a repacked casting room can. 
WSRC-TR-2001-00084

Revision 0

December 18, 2001

Page 29 of 32

Table 5. A list the reported values of scrap cans grouped by component.

\begin{tabular}{|c|c|c|c|}
\hline Assay Date & Can Number & Major Component & $\underset{\text { Content }}{\text { Reported }}{ }^{235} \mathbf{U}$ \\
\hline $11 / 1 / 00$ & 5104 & Not known & 44 \\
\hline $10 / 31 / 00$ & 5302 & Casting Room & 73 \\
\hline $1 / 10 / 01$ & 5507 & Casting Room & 18.8 \\
\hline $1 / 16 / 01$ & 5506 & Casting Room & 0.1 \\
\hline $1 / 16 / 01$ & 5107 & Casting Room & 10.2 \\
\hline $4 / 25 / 00$ & 6402 & Machine Room & 1.2 \\
\hline $1 / 10 / 01$ & 5221 & Machine Room & 4.2 \\
\hline $1 / 10 / 01$ & 5508 & Machine Room & 7.7 \\
\hline $1 / 16 / 01$ & 5419 & Machine Room & 1.2 \\
\hline $1 / 16 / 01$ & 5505 & Machine Room & 1.5 \\
\hline $1 / 16 / 01$ & 5420 & Machine Room & 8.6 \\
\hline $1 / 16 / 01$ & 6008 & Machine Room & 0.1 \\
\hline $8 / 8 / 00$ & 5401 & Machine Room Work Table & 2.2 \\
\hline $11 / 2 / 00$ & 5219 & Machine Room Floor & 1.2 \\
\hline $8 / 8 / 00$ & 5405 & Machine Room Floor & 36.0 \\
\hline $11 / 2 / 00$ & 5217 & Machine Room Cart & 9.4 \\
\hline $11 / 2 / 00$ & 5201 & Decon Machine Vac & 0.2 \\
\hline $11 / 2 / 00$ & 5421 & B Lathe & 15.1 \\
\hline $11 / 2 / 00$ & 5418 & B Lathe & 0.2 \\
\hline $8 / 23 / 00$ & 5504 & B Lathe & 2.0 \\
\hline $8 / 8 / 00$ & 5218 & B Lathe & 0.2 \\
\hline $8 / 23 / 00$ & 5412 & A/C Furnace & 2.4 \\
\hline $8 / 23 / 00$ & 5411 & C Furnace & 9.4 \\
\hline $10 / 31 / 00$ & 3503 & C Casting Furnace & 1.4 \\
\hline $1 / 10 / 01$ & 5106 & C Furnace & 38.8 \\
\hline $11 / 1 / 00$ & 5105 & B Furnace & 1.8 \\
\hline $10 / 31 / 00$ & 5103 & B Furnace Floor Sweepings & 41 \\
\hline $11 / 1 / 00$ & 5102 & B Cyclone Separator & 6.0 \\
\hline $11 / 1 / 00$ & 5304 & Can Vault Machine & 2.6 \\
\hline $10 / 31 / 00$ & 5101 & Floor Sweepings & 3.1 \\
\hline $10 / 31 / 00$ & 5303 & Casting Room Sweepings & 1.5 \\
\hline
\end{tabular}


WSRC-TR-2001-00084

Revision 0

December 18, 2001

Page 30 of 32

\begin{tabular}{|c|c|c|c|}
\hline Date & Can Number & Major Component & $\begin{array}{c}\text { Reported }{ }^{235} \mathrm{U} \\
\text { Content }\end{array}$ \\
\hline $8 / 8 / 00$ & 5315 & Chip Compactor & 26.0 \\
\hline $8 / 8 / 00$ & 5318 & Chip Compactor & 21.0 \\
\hline $8 / 8 / 00$ & 5319 & Chip Compactor & 23.0 \\
\hline $8 / 9 / 00$ & 5320 & Chip Compactor & 18.0 \\
\hline $7 / 6 / 00$ & 5305 & Chip Compactor & 2.3 \\
\hline $7 / 6 / 00$ & 5306 & Chip Compactor & 1.7 \\
\hline $7 / 6 / 00$ & 5307 & Chip Compactor & 1.7 \\
\hline $7 / 6 / 00$ & 5308 & Chip Compactor & 1.7 \\
\hline $7 / 6 / 00$ & 5309 & Chip Compactor & 1.9 \\
\hline $7 / 6 / 00$ & 5310 & Chip Compactor & 3.2 \\
\hline $7 / 12 / 00$ & 5314 & Chip Compactor & 24.2 \\
\hline $7 / 12 / 00$ & 5316 & Chip Compactor & 28.2 \\
\hline $7 / 12 / 00$ & 5317 & Chip Compactor & 7.1 \\
\hline $7 / 12 / 00$ & 5311 & Chip Compactor & 9.9 \\
\hline $7 / 12 / 00$ & 5312 & Chip Compactor & 20.7 \\
\hline $8 / 28 / 00$ & 5413(F Cart) & Freon $^{\mathrm{TM}}$ Cart & 27.5 \\
\hline $8 / 28 / 00$ & 5414(F Cart) & Freon $^{\mathrm{TM}}$ Cart & 28.8 \\
\hline $8 / 28 / 00$ & 5415(F Cart) & Freon $^{\mathrm{TM}}$ Cart & 17.8 \\
\hline $8 / 28 / 00$ & 5416 & NC Lathe & 7.2 \\
\hline $8 / 28 / 00$ & 5417 & NC Lathe & 8.2 \\
\hline $8 / 23 / 00$ & 5501 & NC Lathe & 34.6 \\
\hline $8 / 23 / 00$ & 5503 & NC Lathe & 18 \\
\hline $8 / 23 / 00$ & 5502 & NC Lathe & 36.4 \\
\hline $8 / 8 / 00$ & 5406 & NC Lathe & 0.6 \\
\hline $8 / 8 / 00$ & 5409 & NC Lathe & 11.4 \\
\hline $8 / 8 / 00$ & 5410 & NC Lathe & 23.0 \\
\hline $8 / 8 / 00$ & 5404 & Log Saw & 31.0 \\
\hline $8 / 8 / 00$ & 5407 & Log Saw & 1.8 \\
\hline $8 / 8 / 00$ & 5402 & Log Saw & 13.0 \\
\hline $8 / 8 / 00$ & 5403 & Log Saw & 1.2 \\
\hline $6 / 5 / 01$ & 6205(Lathe) & A-Lathe & 5.3 \\
\hline $6 / 4 / 01$ & 6212(Lathe) & A-Lathe & 20.4 \\
\hline $6 / 4 / 01$ & 6213(Lathe) & A-Lathe & 13.0 \\
\hline $8 / 8 / 00$ & 5408 & Sieving Hood & 19.3 \\
\hline & & & \\
\hline
\end{tabular}




\section{CONCLUSION}

Using a portable HPGe detector with an EG\&G DART ${ }^{\circledR}$ electronics package and an Ortec Gamma-Vision acquisition system and three personal computers, we have assembled a scrap can assay station in Building 324-M to determine HEU content in fixed geometry scrap cans. The scrap cans have been filled during the FDD two-year campaign to deactivate and decommission (D\&D) Building 321-M. During the D\&D campaign, HEU residue recovered from process equipment and from the building floor and exhaust system was packaged into two-gallon scrap cans for subsequent burial as low level waste. Each scrap can was assayed for both criticality safety purposes and MC\&A purposes.

The assay station is a far field transmission-corrected $\gamma$-PHA acquisition system that has been efficiency calibrated in two configurations. It was assembled and operated in a resourceful and efficient manner that allowed us to deliver on-the-spot assay results from both acquisition configurations. Using this assay station we have determined the HEU content of 108 scrap cans that had contents ranging from $<0.1 \mathrm{~g}$ up to $88 \mathrm{~g}$. One of the assay configurations is the traditional point source transmission correction method. The other configuration is one we developed on-site. For this configuration we experimentally obtained a constant-geometry, constant-transmission calibration curve from eight standards assayed from a distance of 48 ". These eight standards yielded an empirical least-squares-curve that we fit with a three-parameter quadratic function using Deming software.

The assay station has proven especially valuable to confirm the holdup assays performed on the 321-M Freon ${ }^{\mathrm{TM}}$ Cart and on the 321-M A-Lathe. Decontamination activities of both of these items of process equipment yielded amounts of HEU residue near $80 \mathrm{~g}$. In both instances by assaying all of the residue in a single can and then splitting the residue into three separate cans and re-assaying, we were able to confirm the utility of the assay station over the entire mass range. This technique of splitting was used to confirm the assays in the upper end of our mass range and served as excellent support of the transmission correction measurements made. The technique of splitting was also very useful for confirmation of assays of scrap cans filled with residue from the casting room. 


\section{REFERENCES}

1. D. L. Honkonen, "Nuclear Criticality Safety Evaluation (NCSE): Enriched Uranium Removal From Building 321-M", N-NCS-G-00051, February 2000.

2. Deactivation Project Plan 321-M Fuel Fabrication Facility, V-PMP-M-00004, January 2000.

3. S. R. Salaymeh and R. A. Dewberry, "HPGe Detector Efficiency Calibration Using HEU Standards," WSRC-TR-2000-00317, September 2000.

4. Deming Least Squares Curve Fitting for Windows, Version 1.13, Safeguards Science and Technology Group (NIS-5), Los Alamos National Laboratory.

5. Norbert Ensslin, "The Art and Science of Holdup Measurements," US Department of Energy Safeguards Technology Training Program, Verification Measurements of Nuclear Material Attributes, August 1987.

6. R. A. Dewberry, S. R. Salaymeh, and F. S. Moore, "High Purity Germanium $\gamma$-PHA Assay of Uranium Storage Pigs For 321-M Facility”, WSRC-TR-2001-00031, June 2001.

7. Raymond A. Dewberry and Saleem R. Salaymeh, "HEU Holdup Measurements on 321-M A-Lathe", WSRC-TR-2001-00296, July 2001.

8. Saleem R. Salaymeh and R. A. Dewberry and Vito R. Casella, "HEU Holdup Measurements in 321-M Freon ${ }^{\mathrm{TM}}$ Cart", WSRC-TR-2000-00360, September 2000.

9. T. D. Hawkins, "Waste Disposal Sheet for High Density Uranium Waste and Holdup Material," SOP-321-1935, multiple revisions, April 2000 - December 2001. 